\title{
Parasitology
}

November 2012, Volume 139 (13), Pages 1757-1771

http://dx.doi.org/10.1017/S0031182012001047

(c) Cambridge University Press 2012

\section{One Perkinsus species may hide another: characterization of Perkinsus species present in clam production areas of France}

\author{
I. Arzul ${ }^{1}$, ${ }^{*}$, B. Chollet ${ }^{1}$, J. Michel ${ }^{1}$, M. Robert ${ }^{1}$, C. Garcia ${ }^{1}$, J.-P. Joly ${ }^{1}$, C. François ${ }^{1}$ and L. Miossec ${ }^{2}$ \\ 1 IFREMER, Laboratory of Genetics and Pathology, Av de Mus de Loup-17390, La Tremblade, France \\ 2 IFREMER, Department of Data Development, Integrated Management and Survey, rue de l'île d'Yeu BP 21105- \\ 44311, Nantes Cedex 03, France \\ *: Corresponding author : Isabelle Arzul, Tel: 0033546762610 ; Fax : 0033546752611 ;
email address : Isabelle.arzul@ifremer.fr
}

\begin{abstract}
:
Although clam populations in France are known to be infected with protozoans of the genus Perkinsus, no molecular characterization was previously performed on these parasites. Considering that several members of this genus have been associated with mortalities of molluscs worldwide, a study was undertaken in order to characterize these parasites in France. For that purpose, clams, Ruditapes philippinarum and $R$. decussatus, collected from different production areas and found to be infected with Perkinsus sp. in thioglycolate culture medium, were selected for PCR-RFLP tests and sequencing. Perkinsus olseni was detected in all the investigated areas and results also suggested the presence of $P$. chesapeaki in Leucate, a lagoon on the Mediterranean coast and in Bonne Anse in Charente Maritime, on the Atlantic coast. Clonal cultures from both detected species were produced in order to describe and compare in vitro stages. Differences in size between both Perkinsus spp. were noticed especially for schizonts and zoosporangia. Lastly, in situ hybridization tests allowed confirmation of the presence of both species in the same $R$. decussatus population and even in same clams. This is the first detection of $P$. chesapeaki in Ruditapes species and outside North America, which questions its introduction into Europe.
\end{abstract}

Keywords : clam parasites ; Perkinsus chesapeaki ; Perkinsus olseni ; Ruditapes philippinarum ; Ruditapes decussatus ; ribosomal RNA; actin; ISH 


\section{INTRODUCTION}

Clam is among the ten most noticeable bivalves produced by European aquaculture. This production mainly relies on two different species: the Japanese carpet shell clam Ruditapes philippinarum and the grooved carpet shell clam $R$. decussatus with an estimated production of $68010 \mathrm{t}$ and $7994 \mathrm{t}$ respectively in 2009 if we include aquaculture and fisheries figures (FAO 2009). In France, clam production, estimated at $1263 \mathrm{t}$ (FAO 2009), is the third most important bivalve one after Crassostrea gigas and mussels. This production is mainly concentrated in Arcachon Bay and South Brittany (D’Hardivillé et al. 2010a and b, Sanchez et al. 2010). However, several natural beds are present along the French coasts including lagoons like Leucate Lagoon or semi-closed bays like Gulf of Morbihan and Bonne Anse in Charente Maritime (Figure 1). The Japanese carpet shell clam is mainly present in North and West of France while the grooved carpet shell clam is dominant in lagoons from the Mediterranean Coast (Garcia et al. 2006). In spite of being fairly well organised and regulated, French clam industry is still facing some problems with economic consequences for producers including diseases such as the brown ring disease due to Vibrio tapetis (Paillard 2004) or the Brown Muscle Disease (Dang et al. 2008). In addition, clam population dynamics may be affected by the presence of parasites belonging to the genus Perkinsus (Lassalle et al. 2007).

Microorganisms of this genus have frequently been associated with important mortality events in different mollusc species worldwide. The first described species in 
this genus was Perkinsus marinus in the 1940s in U.S.A during mass mortality of the American oyster Crassostrea virginica (Ray 1996). Perkinsus olseni was then reported and described in the abalone species Haliotis ruber and H. laevigata in Australia (Lester \& Davis 1981, Goggin \& Lester 1995). A Perkinsus species initially named $P$. atlanticus was described in the grooved carpet shell clam $R$. decussatus following mortality events in Portugal (Azevedo 1989). Molecular investigations demonstrated that $P$. olseni was a senior synonym of $P$. atlanticus (Murrell et al. 2002). More recently other Perkinsus species have been characterized: P. chesapeaki, a parasite of the soft-shell clam Mya arenaria (McLaughin et al. 2000) which is the senior synonym of $P$. andrewsi detected in the Baltic clam Macoma balthica (Burreson et al. 2005) present on the eastern coast of U.S.A.; P. qugwadi associated with mortalities of Japanese scallop Patinopecten yessoensis in Canada (Bower et al. 1998); P. mediterraneus described in flat oysters Ostrea edulis in Balearic Islands, Spain (Casas et al. 2004); P. honshuensis described in the Japanese carpet shell clam R. philippinarum in Japan (Dungan \& Reece 2006) and P. beihaiensis characterized from oyster species Crassostrea ariakensis and C. hongkongensis of Souhern China (Moss et al. 2008). These characterizations are based on initial detection using non specific assays like histology or culture in Ray's Fluid Thioglycolate Medium (RFTM), geographic distribution, host range, parasite morphology especially the description and comparison of different stages of several in vitro isolates and on phylogenic analysis. In Europe, Perkinsus sp. parasites have been reported in France, Spain, Portugal and Italy. However some of these reports are only based on genusspecific assays. Molecular characterization of the 18S and ITS rDNA sequences allowed concluding about the presence of $P$. olseni in Ruditapes decussatus from Catalonia and Galicia in Spain and from Adriatic Sea in Italy (Elandaloussi et al. 
97

98

100

101

102

103

104

105

106

107

108

109

110

111

112

114

2009, Casas et al. 2002, Abollo et al. 2006) and about the presence of $P$. mediterraneus in Ostrea edulis from Balearic Islands (Casas et al. 2004).

While high clam mortality associated with perkinsosis has been recorded in European affected areas (Azevedo 1989, Ruano and Cachola 1986, Figueras et al. 1992,Villalba et al. 1993), the actual impact of perkinsosis on clam production is thus still under debate (Villalba 2008) and seems to be positively related to environmental factors such as water temperature and salinity (Casas et al. 2002, Cigarria et al. 1997, Villalba et al. 2005). Furthermore, Choi, K. et al. (2002) reported that Perkinsus sp. infection levels relate significantly to sediment type: clams living on muddy flats tend to have higher levels of infection than those on sandy tidal flats. Considering the lack of data related to Perkinsus species in France and that infection with Perkinsus olseni is notifiable to the World Organisation for Animal Health (OIE 2011), the study reported here was undertaken to specifically identify parasites of this genus occurring in different French clam growing areas. For that purpose, clams collected from different areas and shown to be infected by RFTM assays were selected for PCR-RFLP tests and sequencing works. Perkinsus olseni was detected in most of the investigated areas and unexpected results were obtained in two locations: Leucate Lagoon in south of France and Bonne Anse in Charente Maritime on the middle West coast of France (Figure 1). Additional sampling was carried out in Leucate Lagoon. Clams were treated in order to study intra- and inter-individual genetic variability of the parasite. Moreover, parasites were cultivated in order to describe in vitro stages. Taken together, results obtained during this study are indicative of the presence of two Perkinsus species $P$. olseni and $P$. chesapeaki in two French clam production areas.

This is the first report of $P$. chesapeaki infections among clams outside of North America, the first report of $P$. chesapeaki infections among Ruditapes decussatus and 
122 . philippinarum clams, and the first report of $P$. chesapeaki in vitro isolates from $123 \quad$ European clams.

124

125

126

MATERIAL AND METHODS

127

128

\section{Sampling}

Clams including Ruditapes decussatus and $R$. philippinarum were collected in October 2004 and 2005 during an epidemiological survey aiming at establishing the distribution, prevalence and infection rates of perkinsosis in main French clam production areas (Figure 1). For some samples, gill tissues were processed for in vitro parasite culture (see section "culture" below). Clams from Golfe of Morbihan, Charente Maritime and Arcachon consisted of Japanese carpet shell clams $R$. philippinarum while clams from Leucate consisted of grooved carpet shell clams $R$. decussatus.

Additional samplings were carried out in Leucate Lagoon (60 clams $R$. decussatus) in October 2008 and in Bonne Anse, Charente Maritime, in September 2010 (30 clams R. philippinarum). Pieces of gills collected from these clams were ground and processed for in vitro parasite culture in order to describe parasite stages (see below section "culture"). Clams from Leucate were also processed in order to test them by in situ hybridization. 
Sixty four samples of cryopreserved or fresh parasite cultures were used for DNA extraction. For cultures obtained from clams collected before 2008, DNA was extracted using the QIAamp DNA minikit (Qiagen) according to the manufacturer's instructions. DNA was eluted and resuspended in a final volume of $50 \mu 1$ of sterile

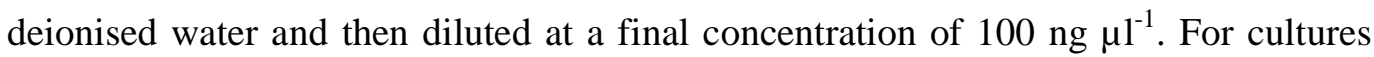
obtained from clams collected in 2008 or after, cells were concentrated by centrifugation (150 $\mathrm{g}$ for $5 \mathrm{~min}$ ) and $100 \mu \mathrm{l}$ of cell suspension (minimum concentration $10^{5}$ cells $\mathrm{ml}^{-1}$ ) were placed and stored on a QIAcard FTA spot (Qiagen) according to the manufacturer's instructions. QIAcard FTA spot was used after 2008 to simplify the handling and processing of DNA from parasite cultures.

\section{PCR, PCR-RFLP, cloning and sequencing}

Three PCR assays targeting sequences of rDNA internal transcribed spacer regions (ITS), large subunit rRNA genes (LSU), and actin-1 genes were used in order to detect and characterize parasites isolated during this study. All the PCR reactions were performed using the Go Taq Polymerase (Promega) in a final volume of $25 \mu 1$. DNA (50-100 ng $\mu \mathrm{l}^{-1}$ or QIAcard FTA disk) was added to $24 \mu \mathrm{l}$ of the PCR mix presented in Table 1. Negative PCR controls consisting of water were included every 10 tested samples in order to check potential contamination. Positive PCR control corresponding to DNA extracted from culture of previously characterized P. olseni from Arcachon Bay was included in each PCR test. 
$37^{\circ} \mathrm{C}$ of $10 \mu \mathrm{l}$ of PerkITS750-85 with 0,25 units of RsaI and Hinfl (Promega). Enzymes were inactivated $20 \mathrm{~min}$ at $65^{\circ} \mathrm{C}$ and the resulting fragment patterns were analysed electrophoretically on $2 \%$ agarose gel. according to manufacturer's recommendations and positive clones were then selected for plasmid DNA purification by FastPlasmid® Mini (Eppendorf). Some plasmidic DNA suspensions were bidirectional sequenced using the Big Dye V3 sequencing kit (Applied Biosystem) and standard M13 forward and reverse primers. Obtained sequences were compared with those included in GenBank using BLAST algorithm (Atschul et al. 1997).

Phylogenetic analyses

184 Available ITS, LSU and actin gene sequences from Perkinsus spp. and dinoflagellates were downloaded from GenBank and included in phylogenetic analyses (Table 2) with sequences obtained in the present study.

Alignments were performed using Clustal W (Thompson et al. 1994) including in MEGA 5 with open and extend gap penalties of seven and three, respectively. Parsimony analyses were also conducted using MEGA version 5 (Tamura et al. 2011) with the close neighbour interchange (CNI) heuristic option. Bootstrap values were calculated over 100 replicates and cut-off value for condensed tree was of $50 \%$. Phylogenetic analysis of the translated actin gene sequences was performed using deduced amino acid sequences. 
194 Genetic distance corresponding to the number of base substitutions per site from 195 averaging over all sequence pairs was estimated using the Tajima-Nei model (Tajima 196 \& Nei 1984) in MEGA5 (Tamura et al. 2011).

197 $\underline{\text { In vitro culture of Perkinsus spp. and cryopreservation }}$ Gill tissues were rinsed three times in sterile sea water (SSW) and then decontaminated twice for $30 \mathrm{~min}$ in $30 \mathrm{ml}$ of SSW supplemented with an antimicrobial suspension (penicillin G 61,3 mg L ${ }^{-1}$; streptomycin sulphate $131 \mathrm{mg} \mathrm{L}^{-}$ ${ }^{1}$; nystatin $50000 \mathrm{U} \mathrm{L}^{-1}$ ). Tissues were rinsed again 3 times in SSW and ground in $250 \mu \mathrm{l}$ of the antimicrobial suspension using a disposable homogenizer. The suspension was mixed and complemented with $750 \mu 1$ of the antimicrobial suspension before incubation for $15 \mathrm{~min}$ at room temperature. Homogenized tissues were centrifuged at $12000 \mathrm{~g}$ for $5 \mathrm{~min}$, supernatants were discarded and pellets were resuspended with $1 \mathrm{ml}$ of SSW. Suspensions were then filtered at $100 \mu \mathrm{m}$ and $50 \mu 1$ of the filtrate were finally inoculated into 6 wells per sample, each containing $1 \mathrm{ml}$ of antimicrobial and salt- supplemented Dulbecco's modified Eagle's/Ham's F12 (1:2) medium (Gauthier \& Vasta 1995, Ordas \& Figueras 1998) in 24-well culture plates. Culture plates were incubated at $26^{\circ} \mathrm{C}$ in humidified air atmosphere chamber and regularly observed under an inverted microscope. cultures according to Gauthier, J.D. and Vasta, G.R. (1995). These clonal cultures were used to describe in vitro parasite stages. Parasites cultures were cryopreserved in medium consisting of $10 \%$ DMSO, $50 \%$ fetal Vasta, G.R. (1995). 
Cells from four clonal cultures from two clams characterized as Perkinsus olseni and cells from three clonal cultures from one clam characterized as $P$. chesapeaki were observed and measured after 16 days of cultures. For that purpose, $20 \mu 1$ of each clonal culture were collected twice and observed microscopically using a Malassezcell haemocytometer. All the cells present in the Malassez-cell haemocytometer were observed in order to estimate proportions of trophozoïtes, schizonts and zoosporangia. Mean cell diameter of each cell type was determined by measuring $100-200$ trophozoïtes and all the schizonts and zoosporangia using the Analysis software (Olympus). Finally, for each Perkinsus species, we estimated the mean proportion and cell diameter of each parasite stage by averaging data obtained from the different conspecific clonal cultures.

\section{$\underline{\text { Histology and in situ hybridization (ISH) }}$}

After 48 hours in Davidson's fixative, half clam soft tissues. were maintained in $70 \%$ ethanol until they were dehydrated and embedded in paraffin for histology according to standard procedures. Paraffin blocks were cut in $2-3 \mu \mathrm{m}$ sections and stained by hematoxylin and eosin.

The protocol followed for ISH was adapted from Moss et al. (2006) and Reece et al. (2008). The digoxigenin-labeled probes consisted of a Perkinsus olseni-specific LSUrRNA gene probe (Moss et al. 2006) PolsLSU-464DIG (5'CTCACAAGTGCCAAACAACTG-3') and Perkinsus chesapeaki-specific LSUrRNA gene probe (Reece et al. 2008) PchesLSU-485DIG (5'-CAG GAA ACA CCA CGC ACK AG-3').

Five $\mu \mathrm{m}$ thick tissue sections on silane-prep ${ }^{\mathrm{TM}}$ slides (Sigma, France) were dewaxed, rehydrated, and treated with proteinase $\mathrm{K}\left(100 \mu \mathrm{g} \mathrm{m} \mathrm{m}^{-1}\right.$ in TE buffer [Tris $50 \mathrm{mM}$, 
EDTA $10 \mathrm{mM}]$ ) at $37^{\circ} \mathrm{C}$ for $5 \mathrm{~min}$. Slides were dehydrated by immersion in an ethanol series and air-dried. Sections were then incubated with $100 \mu 1$ of hybridization buffer (50\% formamide, $10 \%$ dextran sulfate, $4 \times \mathrm{SSC}\left[0.06 \mathrm{M} \mathrm{Na}_{3}\right.$ Citrate, $0.6 \mathrm{M}$ $\mathrm{NaCl}, \mathrm{pH} 7], 250 \mu \mathrm{g} \mathrm{ml}^{-1}$ yeast tRNA and 10\% Denhardt's solution) containing $7 \mathrm{ng}$ $\mu 1^{-1}$ of digoxigenin-labeled probes (Eurogentec). Target DNA and digoxigeninlabeled probe were denatured at $95{ }^{\circ} \mathrm{C}$ for $5 \mathrm{~min}$ and the hybridization was carried out overnight at $42{ }^{\circ} \mathrm{C}$. Sections were washed in $2 \times \mathrm{SSC}$ at room temperature (RT) $(2 \times 5$ $\mathrm{min})$, in $0.4 \times \mathrm{SSC}$ at $42{ }^{\circ} \mathrm{C}(10 \mathrm{~min})$ and in solution $\mathrm{I}(100 \mathrm{mM}$ maleic acid, $0.15 \mathrm{M}$ $\mathrm{NaCl}, \mathrm{pH}$ 7.5) for $5 \mathrm{~min}$. Tissues were then blocked for $30 \mathrm{~min}$ at room temperature with blocking reagent (Amersham Life Science) $(1 \% \mathrm{w} / \mathrm{v})$ in solution I. Specifically bound probe was detected using an alkaline phosphatase-conjugated mouse IgG antibody against digoxigenin diluted at $1.5 \mathrm{U} \mathrm{ml}^{-1}$ in solution $\mathrm{I}(1 \mathrm{~h}, \mathrm{RT})$. Excess of antibody was removed by two washes in solution I (1 min) and one wash in solution II (0.1 M Tris $\mathrm{pH} 8,0.1 \mathrm{M} \mathrm{NaCl}, 0.05 \mathrm{M} \mathrm{MgCl}_{2}, \mathrm{pH}$ 9.5). Slides were incubated in NBT/BCIP, a chromogenic substrate for alkaline phosphatase, diluted in solution II $\left(20 \mu 1 \mathrm{ml}^{-1}\right)$ in the dark until the parasitic cells are completely stained black-purple. The reaction was stopped with solution III (100 mM Tris, 1 mM EDTA, pH 8). Slides were counterstained for 1 min with Bismarck brown yellow $\left(5 \mathrm{mg} \mathrm{ml}^{-1}\right)$, dehydrated with ethanol and mounted in Eukitt resin. Negative controls included samples without digoxigenin- labeled probe in hybridization mixture or without antibodies during colour development. Positive control consisted of sections from Ruditapes philippinarum infected with Perkinsus olseni originating from Arcachon Bay (France) and Mya arenaria infected with P. chesapeaki (kindly provided by Dr R. Carnegie). 
RESULTS

273

274

Characterization of parasites of the genus Perkinsus detected in clam producing $\underline{\text { areas in France }}$

In total, 30 and 33 in vitro Perkinsus sp. isolate cultures were propagated from clams R. philippinarum and R. decussatus respectively (Table 3). Direct PCR-RFLP was performed on five cultures from Arcachon Bay, eight cultures from Morbihan Gulf, 17 cultures from Bonne Anse, Charente Maritime, 33 cultures from Leucate Lagoon (Table 3). Restriction profiles after RsaI and HinfI digestion appeared similar to Perkinsus olseni ones (around 413 bp, 193 bp, 74 bp after digestion with $R s a \mathrm{I}$ and around 363 bp, 160 bp, 150 bp after digestion with Hinfl) for all the tested samples except for seven cultures from five clams collected in Leucate and for 17 cultures from five clams from Bonne Anse, Charente Maritime (Table 3). Indeed, for these cultures, profiles similar to P. chesapeaki one were obtained after RsaI digestion (around 248 bp, 195 bp, 157 bp, 74 bp) (Figure 2). Generally, when several cultures were tested for one clam, RsaI digestion yielded similar restriction profiles. However, for 3 clams collected in 2005 in Leucate Lagoon, both $P$. olseni and $P$. chesapeaki RFLP profiles were obtained from replicate

\section{Genetic variability of the parasite}


obtained on clones were concordant with restriction profiles observed after direct PCR-RFLP. However, in some cases, restriction profiles were different from the profiles described by Abollo, E. et al. (2006) (noted ambiguous in Table 3) or corresponded to $P$. olseni restriction profiles whereas the other clones tested for this culture showed P. chesapeaki profiles.

These clones (which have given ambiguous or unexpected restriction profiles) were selected for sequencing as well as up to 3 clones per culture which have yielded concordant PCR-RFLP results before and after cloning.

In total, 28 sequences were obtained for clones showing Perkinsus olseni restriction profiles as well as ambiguous ones and displayed between 99 and 100\% of identity with P. olseni (U07697). The genetic distance within these sequences was low (0.4\%). These sequences showed between 1 and 3 point nucleotide modifications (mainly substitutions) and concerned one clone. However, four substitutions could be noticed in more than one clone. These substitutions were located in the ITS-2: A instead of G in positions 40 and 54, $\mathrm{G}$ instead of $\mathrm{A}$ in position 158 and $\mathrm{C}$ instead of $\mathrm{T}$ in position 225. Five types of sequence (POa; POb; POc; POd and POe) were finally obtained and deposited in GenBank under accession numbers JQ669641- JQ669645. No correlation could be observed between sequences and individual or geographic origin.

In total, 21 sequences were obtained for clones showing Perkinsus chesapeaki restriction profiles and displayed 96-97\% of identity with P. chesapeaki (AF091541). The overall mean distance between these sequences was $1.6 \%$. Some sequences showed point nucleotide substitutions. However, some modifications could be observed in more than one clone. One substitution ( $\mathrm{T}$ instead of $\mathrm{A}$ ) could be noticed in the ITS-1 (80 bp before the end of the fragment) in three clones obtained from clams 
collected in Charente Maritime (Bonne Anse). In positions 143-145 of the ITS-2, 13

322 sequences showed an insertion of ATA: eight of those were obtained from clams collected in Charente Maritime, and four were from Leucate clams. Finally, four types of sequence (PCa; $\mathrm{PCb} ; \mathrm{PCc}$ and $\mathrm{PCd})$ were obtained and deposited in GenBank under accession numbers JQ669646- JQ669649. Similarly to P. olseni, no correlation could be observed between sequences and individual or geographic origin.

\section{Phylogenetic analyses of Perkinsus olseni and P. chesapeaki strains isolated} during this study

\section{ITS region sequence analysis}

To determine the taxonomic affiliation of Perkinsus species reported in the present study with other congeneric species, phylogenetic analysis was first performed on the rRNA- ITS region.

The different sequence types (9) obtained on the rRNA-ITS region were included in a maximum parsimony (MP) analysis (Figure 3). As expected, the five sequences showing maximum identity with Perkinsus olseni were in the $P$. olseni clade and the four sequences showing maximum identity with $P$. chesapeaki were in the $P$. chesapeaki group. However, the MP analysis revealed with $95 \%$ bootstrap support the existence of a sub clade including only French strains within the $P$. chesapeaki clade (Figure 3). 
LSU and actin-1 sequence analyses

In order to complete the data obtained on the rRNA-ITS region, one culture of the Perkinsus olseni clade and one culture from P. chesapeaki clade were selected for amplification using primers targeting the actin-1 gene region and the LSU region. Both cultures were successfully amplified using PerkActin1-439R and PerkActin1130F. After cloning, three 330 pb-PCR products were sequenced. Two of them were identical and showed maximum identity (98\%) with P. chesapeaki actin-1 (AY876361). The GenBank accession number for this sequence is JQ669650. Last PCR product showed $100 \%$ identity with P. olseni (AY876352). Both cultures were amplified using LSU A and LSU B primers. PCR products were cloned and five 970 bp-clones were sequenced. Three clones showed maximum identity (99\%) with Perkinsus olseni LSU (AY876332) whereas the two other ones showed maximum identity (99\%) with P. chesapeaki (AY876347). These five sequences were deposited in GenBank under the following accession numbers : Phylogenetic analyses performed on the LSU and actin-1 genes supported results obtained on the ITS region: some cultures showing maximum identity on the ITS region with $P$. olseni and P. chesapeaki grouped with the same conspecific strains (Figures 4 and 5). 
Description of in vitro stages of Perkinsus olseni and P. chesapeaki strains isolated from Leucate Lagoon

372

Cells from four clonal cultures from two clams characterized as Perkinsus olseni and cells from three clonal cultures from one clam characterized as $P$. chesapeaki were observed and measured after 16 days of cultures. Cultures of both species were propagated in the DME/Ham's F-12 culture medium, where they proliferated predominantly by schizogony, and to a lesser extent by zoosporulation. Trophozoïtes from both species showed a typical signet ring morphology with a large vacuole and eccentric nucleus with a prominent nucleolus (Figures 6A \& B) and presented comparable mean cell diameter (Table 5). However, P. chesapeaki trophozoites could enlarged up to $41 \mu \mathrm{m}$ while $P$. olseni ones showed maximum cell diameter of $27 \mu \mathrm{m}$.

Perkinsus olseni showed more but smaller schizonts than P. chesapeaki (Table 5, Figure 6A). Finally, only three zoosporangia $(0.2 \%)$ could be observed for P. olseni 


\section{Histology and in situ hybridization}

392

393

Sixty Ruditapes decussatus clams collected during 2008 from Leucate Lagoon were analyzed histologically and by ISH assays with the Perkinsus chesapeaki probe. Twenty of the same clams were also analyzed by ISH assays with the $P$. olseni probe. Fifty one clams were found infected by histology and showed mature trophozoïtes in connective tissue of different organs including gills, mantle, digestive gland, gonad, muscle, heart, kidney and palps. Mature trophozoïtes were characterized by an eccentric vacuole and a signet ring (Figure 7). Several trophozoïtes were observed inside haemocytes or encapsulated in an eosinophylic acellular matrix (Figures 7 and 8) and haemocytes infiltration could be observed closed to the trophozoïtes (Figure 9). Among 60 tested clams, 83\% (50/60) showed specific labeling of parasite cells with the $P$. chesapeaki probe. All $(20 / 20=100 \%)$ tested clams showed labeling of parasite cells by the $P$. olseni probe. Ten clams $(10 / 20=50 \%)$ that showed dual infections through labeling of parasite cells by one of both probes, were selected for comparisons of in vivo tissue tropisms, relative abundances, and morphologies among cells of the co-infecting pathogen species.

Connective tissues of all the organs appeared infected with both probes. Gills, mantle and then digestive gland were more often found infected than kidney palps and heart. Gonad and muscle appeared positive for both assays in one clam. Generally in clams with dual infections, $P$. olseni cells were more abundant and widely distributed than 
414 chesapeaki. Moreover, 1.3 up to 17 times more $P$. olseni were counted than $P$.

415 chesapeaki in co infected clams except in one clam for which this last was twice 416 more abundant than $P$. olseni. Both Perkinsus species could appear as isolated trophozoïtes or in clusters (Figures $10 \mathrm{~A}$ and $\mathrm{B}$ and $11 \mathrm{~A}$ and $\mathrm{B})$. Haemocytic infiltration was observed more frequently associated with $P$. olseni cells (Figure 10A) than with $P$. chesapeaki cells. In histological material, no consistent size differences were detected between cells of the two parasite species $(9,1 \pm 2,8 \mu \mathrm{m}, \mathrm{n}=161$ for $P$. olseni labeled cells; $9,8 \pm 2,9 \mu \mathrm{m}, \mathrm{n}$ $=58$ for $P$. chesapeaki labeled cells $)$.

\section{DISCUSSION}

426

Parasites of the genus Perkinsus have been associated with mortalities of molluscs the genus Perkinsus are known to infect clams in France (Garcia et al. 2006, 
The main objective of the current study was to characterize at the species level, Perkinsus sp. parasites that were detected by genus-specific histological or RFTM assays. For that purpose, parasite cultures obtained from infected clams collected in various French locations were screened by PCR-RFLP according to Abollo, E. et al. (2006). In order to be able to detect potential co infection (infection with several species or strains), PCR products were cloned and several clones were screened again investigated areas and also $P$. chesapeaki like restriction profiles in two locations: Leucate Lagoon in southern France and Bonne Anse in Charente Maritime on the middle Atlantic coast of France. In these locations, replicate cultures from individual clams presented different PCR-RFLP profiles; indicating co-infections by multiple pathogen species. Some clones obtained from clams collected in different places and displaying $P$. olseni and $P$. chesapeaki or ambiguous restriction profiles were selected for sequencing. Phylogenetical analyses confirmed RFLP results and showed that parasites of the genus Perkinsus present in France belong either to $P$. olseni or $P$. chesapeaki clades. However, based on the ITS region parsimony analysis, French $P$. chesapeaki strains appeared slightly different from other conspecific strains and grouped together (95\% bootstrap support). Genetic distances within our isolate strains were low: $0,6 \%$ and $1,6 \%$ for $P$. olseni and $P$. chesapeaki sequences respectively. These values are in the range of the intraspecific variations observed within the currently accepted Perkinsus species (Moss et al. 2008). During the present study, five and four different ITS sequences were obtained for $P$. olseni and $P$. chesapeaki respectively. In a previous study, Reece, K. et al. (2001) showed that allelic and genotypic frequencies differed significantly among Perkinsus marinus strains isolated from three regions of the U.S.A. and those genotypic differences could be related to 
differences in virulence. Based on the analysis of the NTS domain of P. marinus, sequence type frequencies varied according to the geographic origin of the samples (Robledo et al. 1999). In a study on P. olseni cultures, different level of microsatellite polymorphism varied with the geographic origin of the parasites (Vilas et al. 2011). More specifically, Japan and New-Zealand parasites appeared much more variable than those from Spain (Vilas et al. 2011). In our study, we could not observe any relationship between sequence type and geographic origin. This lack of correlation could partly be explained by a low number of sequences to support regional comparison.

The detection of several sequence types (up to 3 different ones) in a same clam can reflect the presence of different $P$. olseni and $P$. chesapeaki strains in a same individual clam as it has been reported for P. marinus (Reece et al. 1997, 2001) and for P. olseni (Vilas et al. 2011). It can also reflect variability in the rRNA locus or between the rRNA repeats in a same Perkinsus sp. strain. Indeed, previous studies suggested that in vitro P. marinus cells are diploids (Reece et al. 1997) and that distinct rRNA units exist in P. andrewsi -newly called P. chesapeaki (Pecher et al. 2004).

In order to confirm and support results obtained on the ITS region, one Perkinsus olseni and one $P$. chesapeaki cultures were selected for further molecular characterization on the LSU and actin 1 genes. Maximum Parsimony analyses performed on both regions confirmed our previous results and allowed us to conclude that $P$. olseni and $P$. chesapeaki are present in France. 
trophozoïtes of both isolates showed vacuolated, signet ring morphology with eccentric nuclei bearing prominent nucleoli. These trophozoïtes presented simultaneous schizogonic and zoosporogonic proliferative cycles. However, in our conditions, zoosporulation was less frequent in P. olseni compared to P. chesapeaki. Schizonts and zoosporangia of $P$. chesapeaki appeared bigger than those of $P$. olseni. Such differences can also be deduced from data available in the literature (Casas et al. 2002, Burreson et al. 2005, Dungan \& Reece, 2006). Compared to these previous observations, $P$. olseni isolated during this study looks very similar in size to other $P$. olseni isolates (Casas et al. 2002, Dungan \& Reece 2006); while the P. chesapeaki isolates of the current investigation showed larger schizonts and smaller zoosporangia than those reported for North American isolates (Coss et al. 2001a, Dungan et al. 2002, Burreson et al. 2005).

Histological examination of infected $R$. decussatus clams from Leucate Lagoon revealed the presence of spherical trophozoites in the connective tissue of many different organs, occasionnally isolated but more often in clusters. Haemocytic infiltration was sometimes observed around infected zones. Parasites could be observed inside haemocytes or encapsulated. ISH allowed distinguishing $P$. chesapeaki and P. olseni in same infected clams. Generally P. olseni appeared more spread out and more abundant. These observations were supported by molecular works. Indeed, direct PCR-RFLP allowed detecting $P$. olseni more frequently than $P$. chesapeaki in Leucate Lagoon.

Infections of different mollusc hosts at the same site by different Perkinsus species and strains have been previously reported (Reece et al. 1997, Dungan \& Reece 
revealed the presence of $P$. marinus and in a lesser extent $P$. chesapeaki in oyster samples from several sites located in Chesapeake Bay (Reece et al. 2008). In our study, $P$. olseni and $P$. chesapeaki appeared sympatric in two distinct locations: in South of France along the Mediterranean sea (Leucate) and in Charente Maritime on the middle West coast of France (Bonne Anse). RFLP results suggested that $P$. chesapeaki was more abundant than $P$. olseni. These apparent abundance differences could be due to the difference which does not support the hypothesis of interspecific competition. our results. No mortality and no population decline were reported in the investigated locations during this study and through the French mollusc health surveillance 
in association with both parasite species, their prevalence and infection intensity in French clam populations should be monitored.

Although the presence of Perkinsus olseni was suspected in France because of the presence of this parasite in other closed European country (Elandaloussi et al. 2009, Casas et al. 2002, Abollo et al. 2006), the detection of P. chesapeaki was more surprising. Indeed, until now this parasite has only been reported in North America and more especially in the soft-shell clam Mya arenaria in Chesapeake Bay (McLaughlin \& Faisal 2000, McLaughlin et al. 2000, Dungan et al. 2002) and the razor clam Tagelus plebeius in Chesapeake and Delaware bays (Dungan et al. 2002, Bushek et al. 2008). The synonymization by Burreson, E. et al. (2005) of $P$. chesapeaki and $P$. andrewsi previously characterized in Macoma balthica from Rhode River, Maryland (Coss et al. 2001b) has consequently enlarged the geographic and host ranges of this parasite. Other clam hosts for P. chesapeaki include: Macoma mitchelli, Mercenaria mercenaria, Mulinia lateralis, Rangia cuneata and Cyrtopleura costata (Burreson et al. 2005, Reece et al. 2008). This is the first description of $P$. chesapeaki in Ruditapes decussatus and $R$. philippinarum and in Europe. Its introduction might have occurred through introduction of susceptible species including Mya arenaria or Mercenaria mercenaria from North America. Mercenaria mercenaria was first introduced to the Atlantic coast of France in 1861 and then to the Mediterranean coast in 1965 (Lambert 1947-1949, Ruckebusch 1947-1949, Bascheri et al. 1965, Goulletquer et al., 2002). In Europe Mya arenaria occurs widely; but it is believed to have been extinct in Pleistocene times and reintroduced by man in historical times (Petersen et al. 1992). 
The work presented herein would require testing the presence of $P$. chesapeaki in

551

552

553

554

555

556

557

558

559

560

561

562

563

564

565 other bivalve species including Mya arenaria or Mercenaria mercenaria and in other European locations, in particular areas where clams were introduced from North America. Apparent co-habitation of $P$. olseni and $P$. chesapeaki in two distinct locations in France also raises interesting questions regarding relationships between these two parasite species as well as parasite-host interactions.

\section{Acknowledgements}

We gratefully acknowledge Dr. K. Reece for her advice before starting this investigation. Esteemed colleague Dr. R. Carnegie generously provided positive control for in situ hybridization (Mya arenaria infected with Perkinsus chesapeaki). Special thanks to referees and Dr. A. Travers for their critical review of this manuscript. We would also like to thank very much Y. Pichot, P. Le Gall, A. Langlade, F. D'Amico, G. Trut, J.-C. Piquet for their participation or their help in facilitating clam collecting. 
Abollo, E., Casas, S.M., Ceschia, G. and Villalba, A. (2006). Differential diagnosis of Perkinsus species by polymerase chain reaction-restriction fragment length polymorphism assay. Molecular and cellular probes. 20, 323-329. doi :10.1016/j.aquaculture.2011.10.017

571

572

573

574

575

576

577

578

579

580

581

582

583

584

585

586

587
Altschul, S.F., Madden, T.L., Schaffer, A.A., Zhang, J., Zhang, Z., Miller, W. and Lipman, D.J. (1997). Gapped BLAST and PSI-BLAST: a new generation of protein data base search programs. Nucleic Acids Research 25, 3389-3402.

Azevedo, C. (1989). Fine structure of Perkinsus atlanticus n. sp. (Apicomplexa, Perkinsea) parasite of clams, Ruditapes decussatus, from Portugal. Journal of Parasitology 75, 627-635.

Bascheri, M.C. (1965). Essai d'acclimatation du clam, Venus mercenaria, en milieu lagunaire méditerranéen (note préliminaire). Rapport du Commité International de la Mer Mediterranée, CIEM 18, 703-714.

Bower, S.M., Blackbourn, J. and Meyer, G.R.. (1998). Distribution, prevalence, and pathogenicity of the protozoan Perkinsus qugwadi in Japanese scallops, Patinopecten yessoensis, cultured in British Columbia, Canada. Canadian Journal of Zoology 76, 954-959.

Burreson, E.M., Reece, K.S. and Dungan, C.F. (2005). Molecular, Morphological, and Experimental Evidence Support the Synonymy of Perkinsus chesapeaki and Perkinsus andrewsi. The Journal of Eukaryotic Microbiology 52, 258-270. doi : 10.1111/j.1550-7408.2005.05-00035.x 
Bushek, D., Landau, B. and Scarpa, E. (2008). Perkinsus chesapeaki in stout razor clams Tagelus plebeius from Delaware Bay. Diseases of Aquatic Organisms 78, 243 247.

Casas, S.M., Villalba, A. and Reece, K.S. (2002). Study of the perkinsosis of the carpet shell clam Tapes decussatus in Galicia (NW Spain). I. Identification of the etiological agent and in vitro modulation of zoosporulation by temperature and salinity. Diseases of Aquatic Organisms 50, 51-65. (2004). Perkinsus mediterraneus $n$. sp., a protistan parasite of the European flat oyster Ostrea edulis from the Balearic Islands, Mediterranean Sea. Diseases of Aquatic Organisms 58, 231-244.

Choi, K.-S., Park, K.-I. Lee, K.-W. and Matsuoka, K. (2002). Infection intensity, prevalence, and histopathology of Perkinsus sp. in the Manila clam, Ruditapes philippinarum, in Isahaya Bay, Japan. Journal of Shellfish Research 21, 119-125. Manila clam Ruditapes philippinarum beds. Diseases of Aquatic Organisms 29, 117Coss, C.A., Robledo, J.A.F. and Vasta, G.R. (2001a). Fine structure of clonally propagated n vitro life stages of a Perkinsus sp. isolated from the baltic clam Macoma balthica. The Journal of Eukaryotic Microbiology 48, 38-51. doi: 10.1111/j.15507408.2001.tb00414.x Perkinsus andrewsi n. sp. isolated from the Baltic clam (Macoma balthica) by 
PCR-based diagnostic assay. The Journal of Eukaryotic Microbiology 48, 52-61. doi:

$613 \quad 10.1111 / \mathrm{j} .1550-7408.2001 . t b 00415 . x$

614 Dang, C., de Montaudouin, X., Gonzalez, P., Mesmer-Dudons, N. and Caill-Milly, 615 N. (2008). Brown muscle disease (BMD), an emergent pathology affecting Manila 616 clam Ruditapes philippinarum in Arcachon Bay (SW France). Diseases of Aquatic $617 \quad$ Organisms 80, 219-228.

618 Dang, C., de Montaudouin, X., Caill-Milly, N. and Željka, T. (2010). Spatio619 temporal patterns of perkinsosis in the Manila clam Ruditapes philippinarum from Arcachon Bay (SW France). Diseases of Aquatic Organisms 91, 151-159. D'Hardivillé, C., Bouché, L. and Péronnet, I. (2010a). Campagne d'évaluation du 622 stock de palourdes de la baie de Vilaine (Pénestin), 16-17 mars 2010. Rapport Ifremer Comité Local des Pêches Maritimes et des élevages marins Auray-Vannes. D’Hardivillé, C., Bouché, L. and Péronnet, I. (2010b). Campagne d'évaluation du stock de palourdes du Golfe du Morbihan, 10-15 mars 2010. Rapport Ifremer Comité Local des Pêches Maritimes et des élevages marins Auray-Vannes. (2002). Two Epizootic Diseases in Chesapeake Bay Commercial Clams Mya arenaria and Tagelus plebeius. Diseases of Aquatic Organisms 50, 67-78 parasites from Japanese Manila clams Venerupis philippinarum and description of Perkinsus honshuensis n. sp. The Journal of Eukaryotic Microbiology 53, 316-326. doi: 10.1111/j.1550-7408.2006.00120.x

Elandaloussi, L., Carrasco, N., Furones, D. and Roque, A. (2009). Phylogenetic relationship of Perkinsus olseni from the Ebro Delta, Spain, to other Perkinsus 
species, based on ribosomal DNA sequences. Diseases of Aquatic Organisms 86, 135-

637 142.

638 Food and Agriculture Organization of the United Nations (FAO) (2009) FishStat Plus -Universal software for fishery statistical time series. Accessed 26 Jan. 2011. http://www.fao.org/fi/statist/FISOFT/FISHPLUS.asp and Perkinsus-like infections in carpet-shell clams, Ruditapes decussatus, of the Ria de Vigo (Galicia NW Spain). Journal of Shellfish Research 11,377-382.

Figueras, A., Robledo, J.A.F. and Novoa, B. (1996). Brown ring disease and parasites in clams (Ruditapes decussatus and $R$. philippinarum) from Spain and Portugal. Journal of Shellfish Research 15, 363-368. and Robert, M. (2006). Bilan 2005 du réseau REPAMO. Rapport Ifremer, LGP, La Tremblade.

Gauthier, J. D. and Vasta, G. R. (1995). In vitro culture of the eastern oyster parasite Perkinsus marinus: optimization of the methodology. Journal of Invertebrate Pathology 66, 156-168.

Goggin, C.L. (1992) Occurrence of parasites of the genus Perkinsus in France. Bulletin of the European Association of Fish Patholology 12,174-176. Goggin, C.L. and Lester, R.J.G. (1995). Perkinsus, a protistan parasite of abalone in Australia: a review. Australian Journal of Marine and Freshwater Resources 46, 639-646. 
Aquatic Species of Europe, (ed. Leppäkkosski et al.), pp. 276-290, Kluwer Academie 661 Publishers, The Netherlands.

Lambert, L. (1947-1949). Note complémentaire sur le clam (Venus mercenaria). Revue des Travaux de l'Office des Pêches Maritimes 15, 118-122.

664 Lassalle, G., de Montaudouin, X., Soudant, P. and Paillard, C. (2007). Parasite co665 infection of two sympatric bivalves, the Manila clam (Ruditapes philippinarum) and the cockle (Cerastoderma edule) along a latitudinal gradient. Aquatic Living Resources 20,33-42. doi: 10.1051/alr:2007013

Lenaers, G., Maroteaux, L., Michot, B. and Herzog, M. (1989). Dinoflagellates in 669 evolution. A molecular phylogenetic analysis of large subunit ribosomal RNA. 670 Journal of Molecular Evolution 29, 40-51. Lester, R.J.G. and Davis, G.H.G. (1981). A new Perkinsus species (Apicomplexa, Perkinsea) from the abalone Haliotis ruber. Journal of Invertebrate Pathology 37, 181-187.

McLaughlin, S.M. and Faisal, M. (2000). Prevalence of Perkinsus spp. in Chesapeake Bay soft-shell clams, Mya arenaria Linnaeus, 1758 during 1990-1998. Journal of Shellfish Research 19, 349-352. McLaughin, S.M., Tall, B.D., Shaheen, A., Elsayed, E.E. and Faisal, M. (2000). Zoosporulation of a new Perkinsus species isolated from the gills of the softshell clam Mya arenaria. Parasite 7, 115-122. infections in Crassostrea ariakensis maintained under laboratory conditions. Journal of Shellfish Research 25, 65-72. doi: $\underline{10.2983 / 0730-}$ $\underline{\text { 8000(2006)25[65:APMIIC]2.0.CO;2 }}$ 
Moss, J.A., Xiao, J., Dungan, C.F. and Reece, K.S. (2008). Description of Perkinsus beihaiensis n. sp., a new Perkinsus sp. Parasite in Oysters of Southern China. The Journal of Eukaryotic Microbiology 55, 117-130. doi: 10.1111/j.15507408.2008.00314.x

Murrell, A., Kleeman, S.N., Barker, S.C. and Lester, R.J.G. (2002). Synonymy of Perkinsus olseni Lester \& Davis, 1981 and Perkinsus atlanticus Azevedo, 1989 and an update on the phylogenetic position of the genus Prekinsus. Bulletin of the European Association of Fish Pathologists 22, 258-265.

OIE, World Organisation for Animal Health (2011). Aquatic Animal Health Code. World Organisation for Animal Health, Paris.

Ordás, M.C. and Figueras, A. (1998). In vitro culture of Perkinsus atlanticus, a parasite of the carpet shell clam Ruditapes decussatus. Diseases of Aquatic Organisms 33, 129-136.

Paillard, C. (2004). A short-review of brown ring disease, a vibriosis affecting clams, Ruditapes philippinarum and Ruditapes decussatus. Aquatic Living Resources 17, 467-475.

Pecher, W.T., Robledo, J.A. and Vasta, G.R. (2004). Identification of a second rRNA gene unit in the Perkinsus andrewsi genome. The Journal of Eukaryotic Microbiology 51, 234-245.

Perkins, F.O. (1996). The structure of Perkinsus marinus (Mackin, Owen, and Collier, 1950) Levine, 1978, with comments on the taxonomy and phylogeny of Perkinsus sp. Journal of Shellfish Research 15, 67-87. 
Ray, S.M. (1996). Historical perspective on Perkinsus marinus disease of oysters in the Gulf of Mexico. Journal of Shellfish Research 15, 9-11.

Reece, K.S., Bushek, D. and Graves, J.E. (1997). Molecular markers for population genetic analysis of Perkinsus marinus. Molecular Marine Biology and Biotechnology 6, 197-206. Reece, K.S., Bushek, D., Hudson, K.L. and Graves, J.E. (2001). Geographic distribution of Perkinsus marinus genetic strains along the Atlantic and Gulf coasts of the USA. Marine Biology 139, 1047-1055. doi: 10.1007/s002270100657 Perkinsus marinus and P. chesapeaki infections among wild oysters and clams in Chesapeake Bay, USA. Diseases of Aquatic Organisms 82, 237-248. Robledo, J.A.F., Wright, A.C., Marsh, A.G. and Vasta, G.R. (1999). Nucleotide sequence variability in the nontranscribed spacer of the rRNA locus in the oyster parasite Perkinsus marinus. The Journal of Parasitology 85, 650-656. marinus (Levin-78) at Ria de Faro clam's culture beds. In: Abstracts of the Second International Colloquium on Pathology in Marine Aquaculture (PAMAQ II) University of Oporto, Porto, Portugal, p 41-42 Ruckebusch, H. (1947-1949). Le clam. Note sur Venus mercenaria L. Son introduction et son élevage dans le bassin de la Seudre. Revue des Travaux de l'Office des Pêches Maritimes 15, 99-117.

Sanchez, F., Caill-Milly, N., Lissardy, M., de Casamajor, M-N. and Morandeau G. (2010). Campagne d'évaluation du stock de palourdes du bassin d'Arcachon, année 2010. Rapport Ifremer R.INT.DCN/HGS/LRHA 10-004. 
Tajima, F. and Nei, M. (1984). Estimation of evolutionary distance between nucleotide sequences. Molecular Biology and Evolution 1, 269-285. MEGA5: Molecular Evolutionary Genetics Analysis using Maximum Likelihood, Evolutionary Distance, and Maximum Parsimony Methods. Molecular Biology and Evolution (In Press). Doi: 10.1093/molbev/msr121

Thompson, J. D., Higgins, D. G. and Gibson, T. J. (1994). CLUSTAL W: improving the sensitivity of progressive multiple sequence alignment through sequence weighting, positions-specific gap penalties and weight matrix choice. Nucleic Acid Research 22, 4673-4680. (2011). Very low microsatellite polymorphism and large heterozygote deficits suggest founder effects and cryptic structure in the parasite Perkinsus olseni. Infection, Genetics and Evolution 11, 904-911. doi: 10.1016/j.meegid.2011.02.015. Perkinsosis in molluscs: A review. Aquatic Living Resources 17, 411-432. Villalba, A. (2008). Workshop for the analysis of the impact of Perkinsosis to the European Shellfish Industry. Centro de Investigacións Mariñas, Conseillería de Pesca e Asuntos Marítimos da Xunta de Galicia, Vilanova de Arousa, Spain. patologicas de tres especies de almeja Ruditapes decussatus, Venerupis pullastra y Venerupis rhomboides en las rias gallegas. In: Cervino, Landin, Coo, Guerra, Torre (eds) Actas del IV Congreso Nacional de Acuicultura. 21-24 September 1993. Vilanova de Arousa, p 551-556 
Villalba, A., Casas, S.M., Lopez, C. and Carballal, M.J. (2005). Study of perkinsosis in the carpet shell clam Tapes decussatus in Galicia (NW Spain). II. Aquatic Organisms 65, 257-267.

760

761

762

763

764

765 


\section{Figure caption}

768

769

770

Figure 1. Locations where clams Ruditapes decussatus or $R$. philippinarum were collected for the current study.

772

773

774

775

776

777

778

779

780

781

782

783

784

785

786

Figure 2. Restriction profiles obtained after RsaI digestion of Perk ITS750-85 PCR products from clams collected in 2005 in Leucate Lagoon. Lanes 2-7 and 10 and 11 show Perkinsus olseni-P. mediterraneus restriction profiles (around 413 bp, 193 bp and $74 \mathrm{bp}$ ) while lanes 8 and 9 show $P$. chesapeaki restriction profiles (around $248 \mathrm{bp}$, 195 bp, 157 bp, and 74 bp). Lanes 1 and 12 show a 100-bp ladder (Smartladder, Eurogentec).

Figure 3. Maximum Parsimony analysis showing the taxonomic position of Perkinsus ITS sequences obtained in the present study. Numbers at branch nodes indicate bootstrap confidence values in percent. The analysis included 57 nucleotide sequences and was conducted using 841 aligned nucleotide positions. Sequences (Accession numbers) obtained in this study were : POa (JQ669641); POb (JQ669642); POc (JQ669643); POd (JQ669644); POe (JQ669645); PCa (JQ669646); PCb (JQ669647); PCc (JQ669648) and PCd (JQ669649). (*) sequences obtained in this study. 
Figure 4. Maximum Parsimony analysis showing the taxonomic position of Perkinsus

791

792

793

794

795

796

797

798

799

800

801

802

803

804

805

806

807

808

809

810

811

Actin 1 gene sequences obtained in the present study. Numbers at branch nodes indicate bootstrap confidence values in percent. The analysis included 28 amino acid sequences and was conducted using 88 aligned amino acid positions. (*) sequences obtained in this study.

Figure 5. Maximum Parsimony analysis showing the taxonomic position of Perkinsus large subunit (LSU) rRNA gene sequences obtained in the present study. Numbers at branch nodes indicate bootstrap confidence values in percent. The analysis included 32 nucleotide sequences and was conducted using 984 aligned nucleotide positions. (*) sequences obtained in this study.

Figures 6A, B and C. In vitro Perkinsus olseni (6A) and P. chesapeaki (6B-C) cultures obtained from Ruditapes decussatus clams (Leucate Lagoon). 6ATrophozoïte $(\mathrm{T})$ showing a typical signet-ring morphology with a large vacuole and eccentric nucleus, schizont (S) containing numerous daughter cells, cluster (C) of sibling daughter trophozoites. 6B- Trophozoïte (T) showing a typical signet-ring morphology with a large vacuole and eccentric nucleus, zoosporangium (arrow) with probable discharge tube (*). 6C- Zoosporangium (arrow) with extended discharge tube $(*)$ enclosing hundreds zoospores. Scale bars $=50 \mu \mathrm{m}$. 
812 Figure 7-9. H\&E-stained tissue section showing Perkinsus trophozoïtes in tissues of 813 Ruditapes decussatus from Leucate Lagoon. 7 Cluster of mature trophozoïtes inside 814 an eosinophilic acellular matrix (*) showing an eccentric vacuole and a signet ring 815 located in the connective tissue of the mantle. 8. Isolated or grouped trophozoïtes 816 located in the connective tissue of the mantle. Parasite clusters are associated with 817 eosinophilic acellular matrix $(*) .9$. Isolated and grouped trophozoïtes associated with 818 an important infiltration of hameocytes in the connective tissue of the digestive gland. Figures 10A and B. In situ hybridization assay using Perkinsus olseni probe on a clam Ruditapes decussatus from Leucate Lagoon. A. Positive isolated and grouped trophozoïtes in the connective tissue of gills. The presence of the parasites is associated with a strong haemocytic infiltration. B. Positive isolated and grouped trophozoïtes in the connective tissue of the digestive gland.

825 Figures $11 \mathrm{~A}$ and B. In situ hybridization assay using Perkinsus chesapeaki probe on a clam Ruditapes decussatus from Leucate Lagoon. A. Encapsulated positive trophozoïtes in the connective tissue of the digestive gland. B. Positive isolated and grouped trophozoïtes in the gonadal connective tissue.

830

831 
Tables

Table 1. Conditions and primer sequences used for the PCR assays

\begin{tabular}{|c|c|c|c|c|}
\hline & & ITS & LSU & Actin \\
\hline \multirow{5}{*}{$\begin{array}{l}\text { PCR } \\
\text { mix } \\
\text { compo } \\
\text { sition }\end{array}$} & $\mathrm{MgCl} 2(\mathrm{mM})$ & 2.5 & 1.5 & 3 \\
\hline & $\mathrm{BSA}(\mu \mathrm{g} / \mathrm{ml})$ & 0.4 & 0.125 & $210^{-4}$ \\
\hline & $\mathrm{dNTP}(\mathrm{mM})$ & 0.25 & 0.2 & 0.1 \\
\hline & Primers $(\mu \mathrm{M})$ & 0.2 & 1 & 1 \\
\hline & $\begin{array}{l}\text { Taq polymerase } \\
\text { (units/ml) }\end{array}$ & 0.04 & 0.025 & 0.125 \\
\hline \multicolumn{2}{|c|}{ Amplification programme } & $\begin{array}{l}4 \text { min at } 95^{\circ} \mathrm{C} \\
40 \text { cycles } \\
\left(1 \text { min at } 95^{\circ} \mathrm{C} \text {, }\right. \\
1 \text { min at } 65^{\circ} \mathrm{C} \text {, } \\
\left.1 \text { min at } 72^{\circ} \mathrm{C}\right) \\
5 \text { min at } 72^{\circ} \mathrm{C}\end{array}$ & $\begin{array}{l}4 \text { min at } 94^{\circ} \mathrm{C} \\
35 \text { cycles } \\
\left(30 \text { s at } 94^{\circ} \mathrm{C}\right. \\
30 \text { s at } 55^{\circ} \mathrm{C} \\
\left.2 \text { min at } 65^{\circ} \mathrm{C}\right) \\
5 \text { min at } 65^{\circ} \mathrm{C}\end{array}$ & $\begin{array}{l}5 \text { min at } 95^{\circ} \mathrm{C} \\
40 \text { cycles } \\
\left(1 \text { min at } 95^{\circ} \mathrm{C},\right. \\
45 \mathrm{~s} \text { at } 58,5^{\circ} \mathrm{C}, \\
\left.1 \text { min at } 68^{\circ} \mathrm{C}\right) \\
5 \text { min at } 68^{\circ} \mathrm{C}\end{array}$ \\
\hline \multicolumn{2}{|c|}{ Size of the amplicons } & 703 bp & $+\sqrt{20}$ & $300 \mathrm{bp}$ \\
\hline \multicolumn{2}{|c|}{ Reference } & Casas et al. 2002 & Lenaers et al. 1989 & Moss et al. 2008 \\
\hline \multirow{2}{*}{$\begin{array}{l}\text { Forward } \\
\text { primer }\end{array}$} & Name & Perk ITS 750 & LSU A & PerkActin1130F \\
\hline & $\begin{array}{l}\text { Sequence } \\
\left(5^{\prime} 3^{\prime}\right)\end{array}$ & ACATCAGGCCTTCTAATGATG & ACCCGCTGAATTTAAGCATA & ATGTATGTCCAGATYCAGGC \\
\hline \multirow{2}{*}{$\begin{array}{l}\text { Reverse } \\
\text { primer }\end{array}$} & Name & Perk ITS 85 & LSU B & PerkActin1-439R \\
\hline & $\begin{array}{l}\text { Sequence } \\
\left(5^{\prime} 3^{\prime}\right)\end{array}$ & CCGCTTTGTTTGGATCCCC & ACGAACGATTTGCACGTCAG & CTCGTACGTTTTCTCCTTCTC \\
\hline
\end{tabular}


Table 2. GenBank accession numbers of rRNA-ITS, rRNA-LSU and actin-1 gene sequences used in phylogenetic analyses

\begin{tabular}{|c|c|c|}
\hline Region of the parasite genome & Perkinsus species & GenBank accession number \\
\hline \multirow[t]{9}{*}{ rRNA-ITS } & Perkinsus chesapeaki & $\begin{array}{l}\text { AF091541, AF102171, AF252288, AF440464, AF440466, AF440468, } \\
\text { AY876302-AY876307, AY305326, EU919470, EU919484 }\end{array}$ \\
\hline & Perkinsus olseni & $\begin{array}{l}\text { AF140295, AF369967,AF369969, AF441211, AF441213, AF473840, } \\
\text { AF522321, AY435092, UO7697 }\end{array}$ \\
\hline & Perkinsus marinus & AY295188, AY295189, AY295194, AF150987, AF091542, UO7700 \\
\hline & Perkinsus mediterraneus & EU068096, EU068098, DQ370482, DQ370483, AY487839 \\
\hline & Perkinsus beihaiensis & EF204015, EU068095, EF204050, EU068080 \\
\hline & Perkinsus honshuensis & Q516701, DQ516696, DQ516697, DQ516698, DQ516699, DQ516700 \\
\hline & Symbiodinium sp. & AF360576 \\
\hline & Prorocentrum micans & AY465117 \\
\hline & Perkinsus qugwadi & AF151528 \\
\hline \multirow[t]{7}{*}{ rRNA-LSU gene } & Perkinsus chesapeaki & AY876344- 49 \\
\hline & Perkinsus olseni & AY876330-32 \\
\hline & Perkinsus marinus & AY876319, AY876320, AY876322, AY876325, AY876328, AY876329 \\
\hline & Perkinsus mediterraneus & EF204095-98, EF204100 \\
\hline & Perkinsus beihaiensis & EF526448, EF526451 \\
\hline & Perkinsus honshuensis & DQ516680-82, DQ516684 \\
\hline & Prorocentrum micans & X16108 \\
\hline \multirow[t]{8}{*}{ Actin-1 } & Perkinsus chesapeaki & AY876359-61 \\
\hline & Perkinsus olseni & AY876352, AY876355-57, EF204109-11 \\
\hline & Perkinsus marinus & U84287, U84288, AY876350 \\
\hline & Perkinsus mediterraneus & EF204112-15 \\
\hline & Perkinsus beihaiensis & EF526411-12 \\
\hline & Perkinsus honshuensis & DQ516686-89 \\
\hline & Prorocentrum micans & U84290 \\
\hline & Amphidinium carterae & U84289 \\
\hline
\end{tabular}


Table 3. Number of tested clams and cultures tested per clam for each locations included in the present study. The sixth column presents number of restriction profile types obtained by direct PCR-RFLP $(\mathrm{PO}=$ Perkinsus olseni and $\mathrm{PC}=$ Perkinsus chesapeaki). The following columns present results after cloning PCR products. The last column indicates the obtained sequence types $(\mathrm{POa}=\mathrm{JQ669641}$; POb $=\mathrm{JQ669642}$; POc= JQ669643; POd= JQ669644; POe= JQ669645; PCa= JQ669646; PCb = JQ669647; PCc = JQ669648; PCd = JQ669)

\begin{tabular}{|c|c|c|c|c|c|c|c|c|c|}
\hline Area & Site & year & $\begin{array}{l}\text { number } \\
\text { of clams }\end{array}$ & $\begin{array}{c}\text { number } \\
\text { of } \\
\text { cultures }\end{array}$ & $\begin{array}{l}\text { PCR- } \\
\text { RFLP }\end{array}$ & $\begin{array}{l}\text { Number of } \\
\text { cloned PCR } \\
\text { products }\end{array}$ & $\begin{array}{l}\text { Number of } \\
\text { clones tested } \\
\text { by RFLP }\end{array}$ & PCR-RFLP & Sequences \\
\hline \multirow{2}{*}{$\begin{array}{c}\text { Arcachon } \\
\text { (Ruditapes } \\
\text { philippinarum) }\end{array}$} & Les Argiles & 2004 & 3 & 3 & $3 \mathrm{PO}$ & 2 & 46 & $\begin{array}{l}45 \mathrm{PO}+1 \\
\text { ambiguous }\end{array}$ & $4 \mathrm{PO}(2 \mathrm{POa} ; 2 \mathrm{POc})$ \\
\hline & $\begin{array}{l}\text { Château } \\
\text { Madère }\end{array}$ & 2005 & 1 & 2 & $2 \mathrm{PO}$ & 2 & 28 & $\begin{array}{c}27 \mathrm{PO}+1 \\
\text { ambiguous }\end{array}$ & $5 \mathrm{PO}(4 \mathrm{POa} ; 1 \mathrm{POb})$ \\
\hline \multirow{3}{*}{$\begin{array}{c}\text { Leucate } \\
\text { (Ruditapes } \\
\text { decussatus) }\end{array}$} & Nord 2 & 2005 & 4 & 5 & $5 \mathrm{PO}$ & 2 & 19 & $19 \mathrm{PO}$ & $2 \mathrm{PO}(2 \mathrm{POa})$ \\
\hline & \multirow[b]{2}{*}{ Nord 1} & 2005 & 6 & 12 & $\begin{array}{l}9 \mathrm{PO} \\
3 \mathrm{PC}\end{array}$ & 8 & 68 & $\begin{array}{l}44 \text { PO } 22 \text { PC } \\
2 \text { ambiguous }\end{array}$ & $\begin{array}{c}10 \mathrm{PO}(9 \mathrm{POa} ; 1 \mathrm{POe}) \\
7 \mathrm{PC}(4 \mathrm{PCc} ; 3 \mathrm{PCd})\end{array}$ \\
\hline & & 2008 & 13 & 16 & $\begin{array}{c}4 \mathrm{PC} \\
12 \\
\mathrm{PO}\end{array}$ & \multicolumn{3}{|c|}{ Not done } & $\begin{array}{c}3 \mathrm{PO}(3 \mathrm{POa}) \\
4 \mathrm{PC}(3 \mathrm{PCc} ; 1 \mathrm{PCd})\end{array}$ \\
\hline $\begin{array}{c}\text { Golfe du } \\
\text { Morbihan } \\
\text { (Ruditapes } \\
\text { philippinarum) }\end{array}$ & Ile Tascon & 2005 & 3 & 3 & $3 \mathrm{PO}$ & 2 & 18 & $18 \mathrm{PO}$ & $1 \mathrm{PO}(1 \mathrm{POd})$ \\
\hline
\end{tabular}




\begin{tabular}{|c|c|c|c|c|c|c|c|c|c|}
\hline & Le Lern & 2005 & 2 & 5 & $5 \mathrm{PO}$ & 2 & 14 & $14 \mathrm{PO}$ & $1 \mathrm{PO}(1 \mathrm{POc})$ \\
\hline $\begin{array}{c}\text { Charente } \\
\text { Maritime } \\
\text { (Ruditapes } \\
\text { philippinarum) }\end{array}$ & Bonne Anse & 2010 & 5 & 17 & $17 \mathrm{PC}$ & 6 & 80 & $77 \mathrm{PC} 3 \mathrm{PO}$ & $\begin{array}{c}10 \mathrm{PC}(1 \mathrm{PCa} ; 2 \mathrm{PCb} ; 1 \mathrm{PCc} ; 6 \mathrm{PCd}) \\
2 \mathrm{PO}(1 \mathrm{POa} ; 1 \mathrm{POe})\end{array}$ \\
\hline
\end{tabular}


Table 4. Results obtained for six clams Ruditapes decussatus collected in Leucate Lagoon in 2005. Between one and three cultures (noted I to III) were obtained for each clam. The third column presents restriction profile types obtained by direct PCR-RFLP $(\mathrm{PO}=$ Perkinsus olseni and $\mathrm{PC}=$ Perkinsus chesapeaki). The following columns present results after cloning PCR products. The last column indicates the obtained sequence types (POa = JQ669641; POe= JQ669645; PCc = JQ669648; PCd = JQ669649 )

\begin{tabular}{|c|c|c|c|c|c|}
\hline Clam number & Culture number & PCR-RFLP & Number of cloned PCR products & PCR-RFLP & Sequences \\
\hline \multirow{3}{*}{1} & $\mathrm{I}$ & $\mathrm{PO}$ & $\begin{array}{l}0 \\
-10\end{array}$ & $10 \mathrm{PO}$ & $1 \mathrm{POa}$ \\
\hline & II & $\mathrm{PC}$ & 2 & $2 \mathrm{PC}$ & $2 \mathrm{PCc}$ \\
\hline & III & $\mathrm{PO}$ & Not done & Not done & \\
\hline \multirow{2}{*}{2} & I & $\mathrm{PO}$ & Not done & Not done & \\
\hline & II & $\mathrm{PC}$ & 9 & $9 \mathrm{PC}$ & $1 \mathrm{PCc}, 1 \mathrm{PCd}$ \\
\hline \multirow{2}{*}{3} & I & $\mathrm{PO}$ & 6 & $6 \mathrm{PO}$ & $1 \mathrm{POa}$ \\
\hline & II & $\mathrm{PO}$ & Not done & Not done & \\
\hline 4 & I & $\mathrm{PC}$ & 10 & $10 \mathrm{PC}$ & $2 \mathrm{PCd}, 1 \mathrm{PCc}$ \\
\hline
\end{tabular}




\begin{tabular}{|c|c|c|c|c|c|}
\hline & II & PO & 1 & 1 PO & 1 POa \\
\hline \multirow{2}{*}{5} & I & PO & 9 & 7 PO and 2 ambiguous & 4 POa, 1POe \\
\cline { 2 - 6 } & II & PO & Not done & Not done & \\
\hline 6 & I & PO & 20 & 20 PO & 2 POa \\
\hline
\end{tabular}


Table 5. Mean diameters, diameter ranges and proportional abundances of the different parasite stages observed for the in vitro culture of Perkinsus olseni and P. chesapeaki

\begin{tabular}{|c|c|c|c|c|c|c|c|c|}
\hline & \multicolumn{4}{|c|}{ Perkinsus chesapeaki } & \multicolumn{4}{|c|}{ Perkinsus olseni } \\
\hline & $\begin{array}{c}\text { Mean } \\
\text { diameter } \\
(\mu \mathrm{m})\end{array}$ & $\begin{array}{c}\text { Diameter } \\
\text { range } \\
(\mu \mathrm{m}) \\
\end{array}$ & Number & $\begin{array}{c}\text { Abundance } \\
(\%)\end{array}$ & $\begin{array}{c}\text { Mean } \\
\text { diameter } \\
(\mu \mathrm{m})\end{array}$ & $\begin{array}{c}\text { Diameter } \\
\text { range } \\
(\mu \mathrm{m}) \\
\end{array}$ & Number & $\begin{array}{l}\text { Abundance } \\
(\%)\end{array}$ \\
\hline Trophozoïtes & 10.7 & $3.5-41.4$ & 936 & $63.3 \%$ & 9.7 & $3.7-27.4$ & 1,048 & $58.1 \%$ \\
\hline Schizonts & 34.5 & $10.8-62.9$ & 277 & $18.7 \%$ & 18.2 & $6.0-40.1$ & 752 & $41.7 \%$ \\
\hline Zoosporangia & 39 & $21.1-63.9$ & 265 & $17.9 \%$ & 24.4 & $22.7-27.4$ & 3 & $0.2 \%$ \\
\hline
\end{tabular}




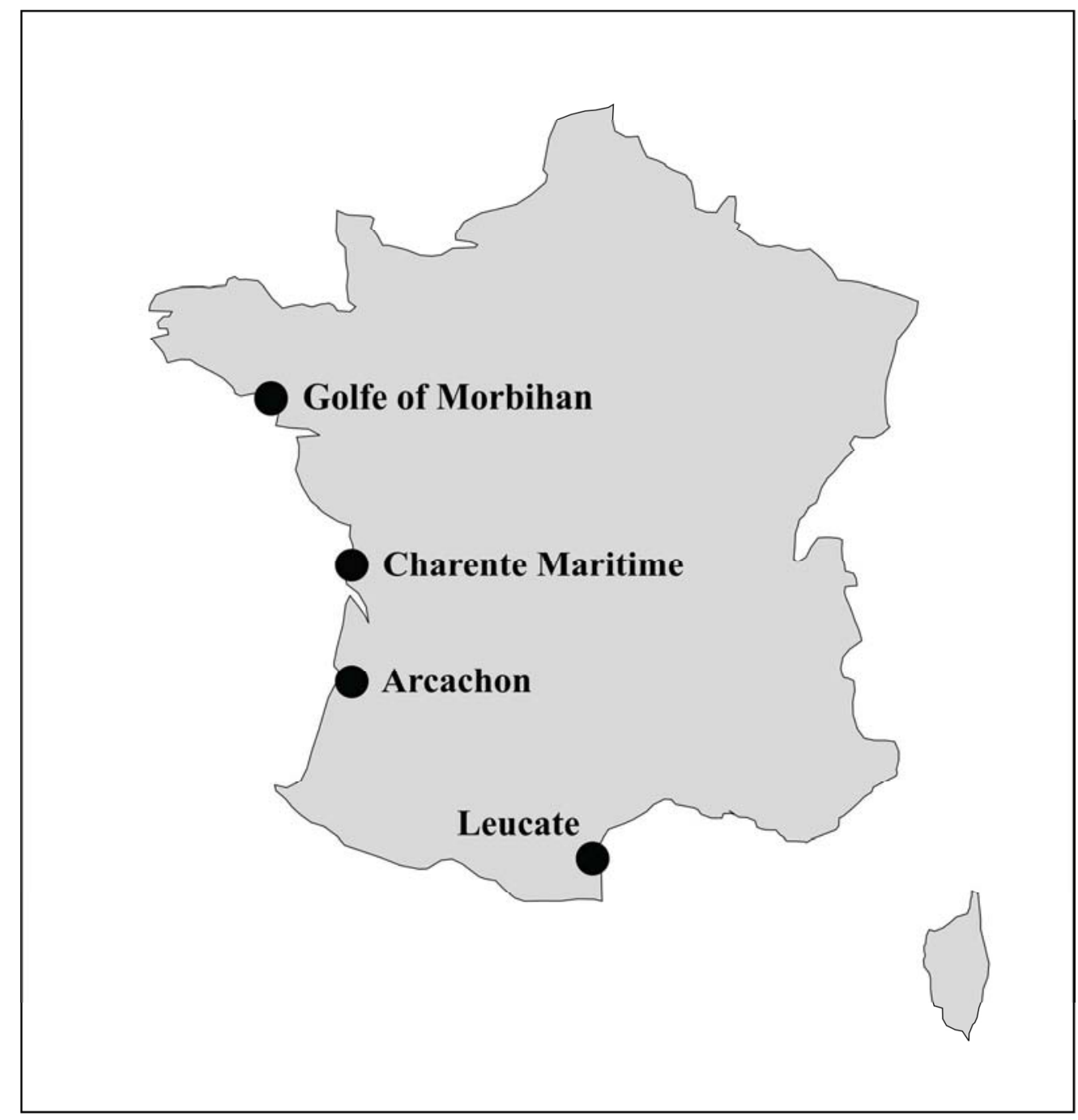

Figure 1. Locations where clams Ruditapes decussatus or R. philippinarum were collected for the current study. 


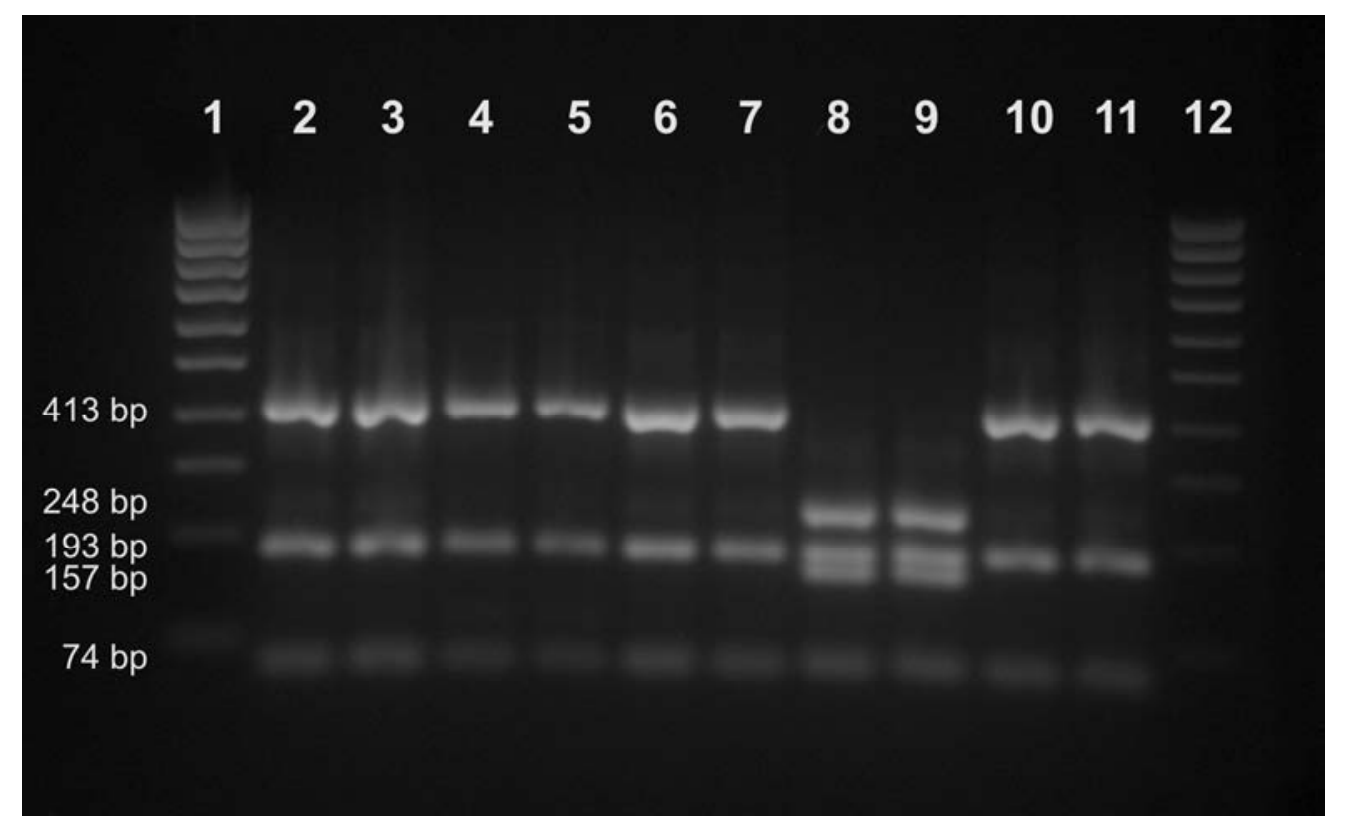

Figure 2. Restriction profiles obtained after RsaI digestion of Perk ITS750-85 PCR products from clams collected in 2005 in Leucate Lagoon. Lanes 2-7 and 10 and 11 show Perkinsus olseni-P. mediterraneus restriction profiles (around $413 \mathrm{bp}, 193 \mathrm{bp}$ and $74 \mathrm{bp}$ ) while lanes 8 and 9 show P. chesapeaki restriction profiles (around 248 bp, 195 bp, 157 bp, and 74 bp). Lanes 1 and 12 show a 100-bp ladder (Smartladder, Eurogentec). 


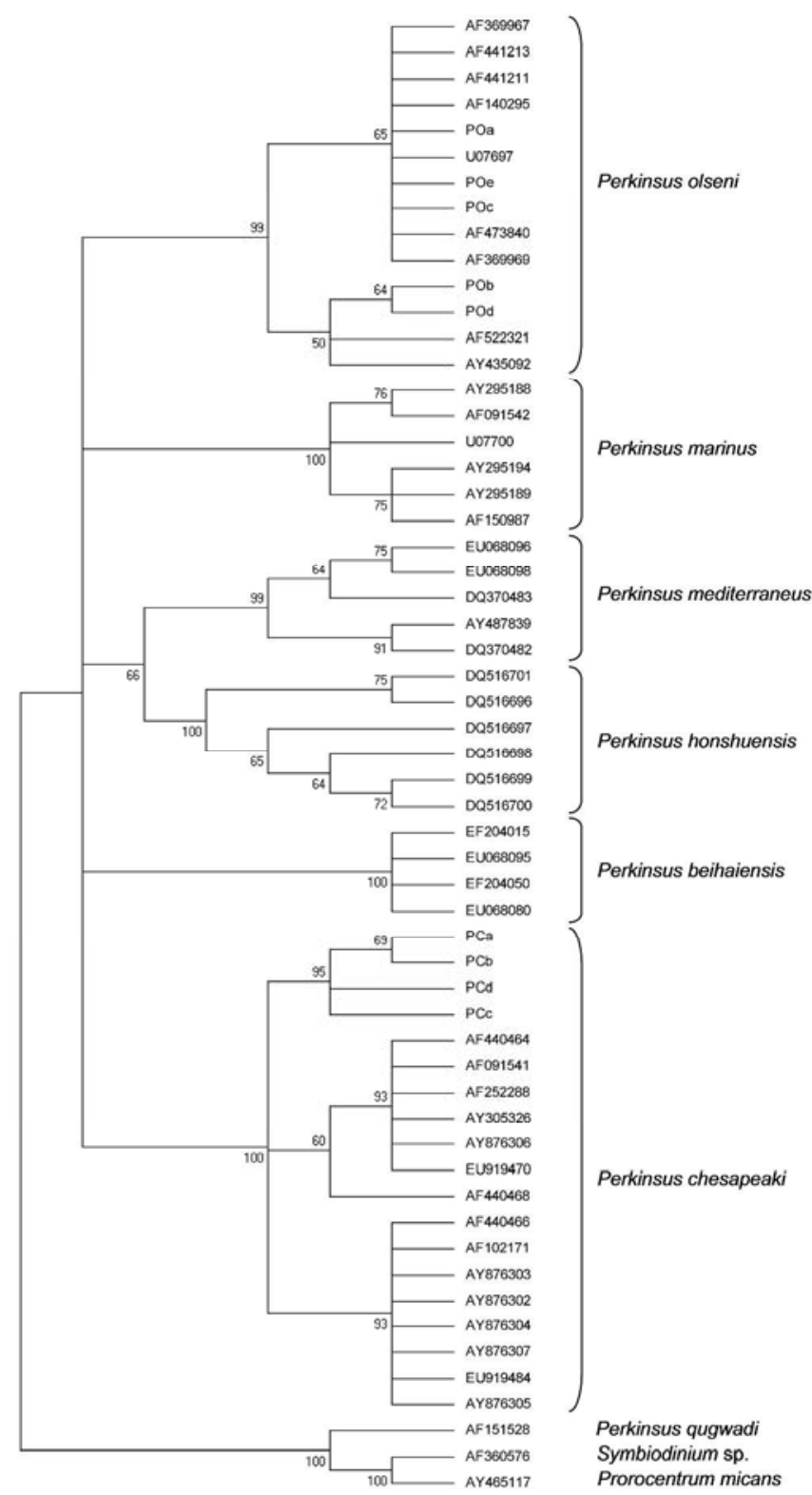

Figure 3. Maximum Parsimony analysis showing the taxonomic position of Perkinsus ITS sequences obtained in the present study. Numbers at branch nodes indicate bootstrap confidence values in percent. The analysis included 57 nucleotide sequences and was conducted using 841 aligned nucleotide positions. Sequences (Accession numbers) obtained in this study were : POa (JQ669641); POb (JQ669642); POc (JQ669643); POd (JQ669644); POe (JQ669645); PCa (JQ669646); PCb (JQ669647); PCc (JQ669648) and PCd (JQ669649).

$(*)$ sequences obtained in this study. 


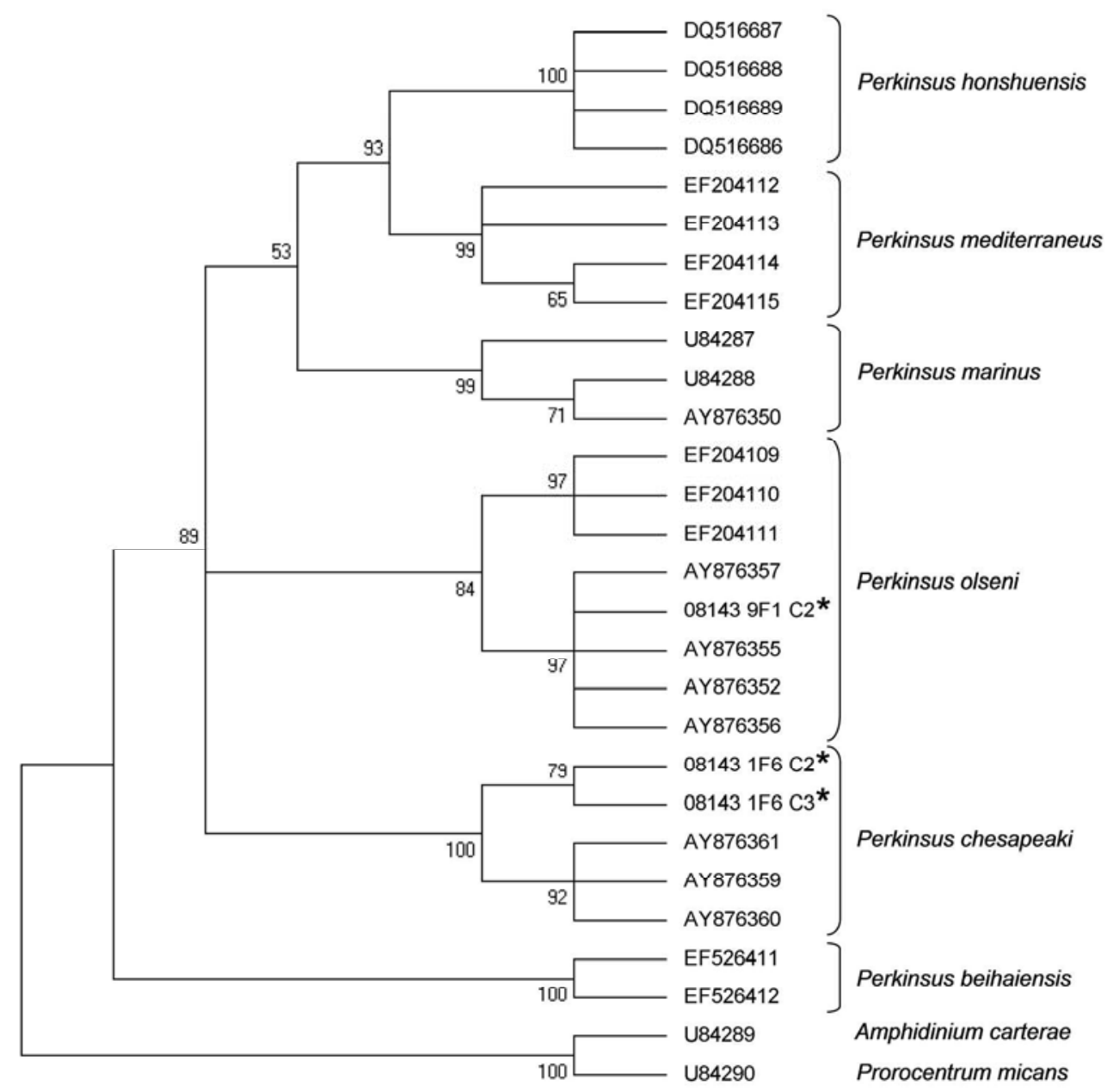

Figure 4. Maximum Parsimony analysis showing the taxonomic position of Perkinsus Actin 1 gene sequences obtained in the present study. Numbers at branch nodes indicate bootstrap confidence values in percent. The analysis included 28 amino acid sequences and was conducted using 88 aligned amino acid positions.

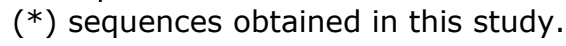




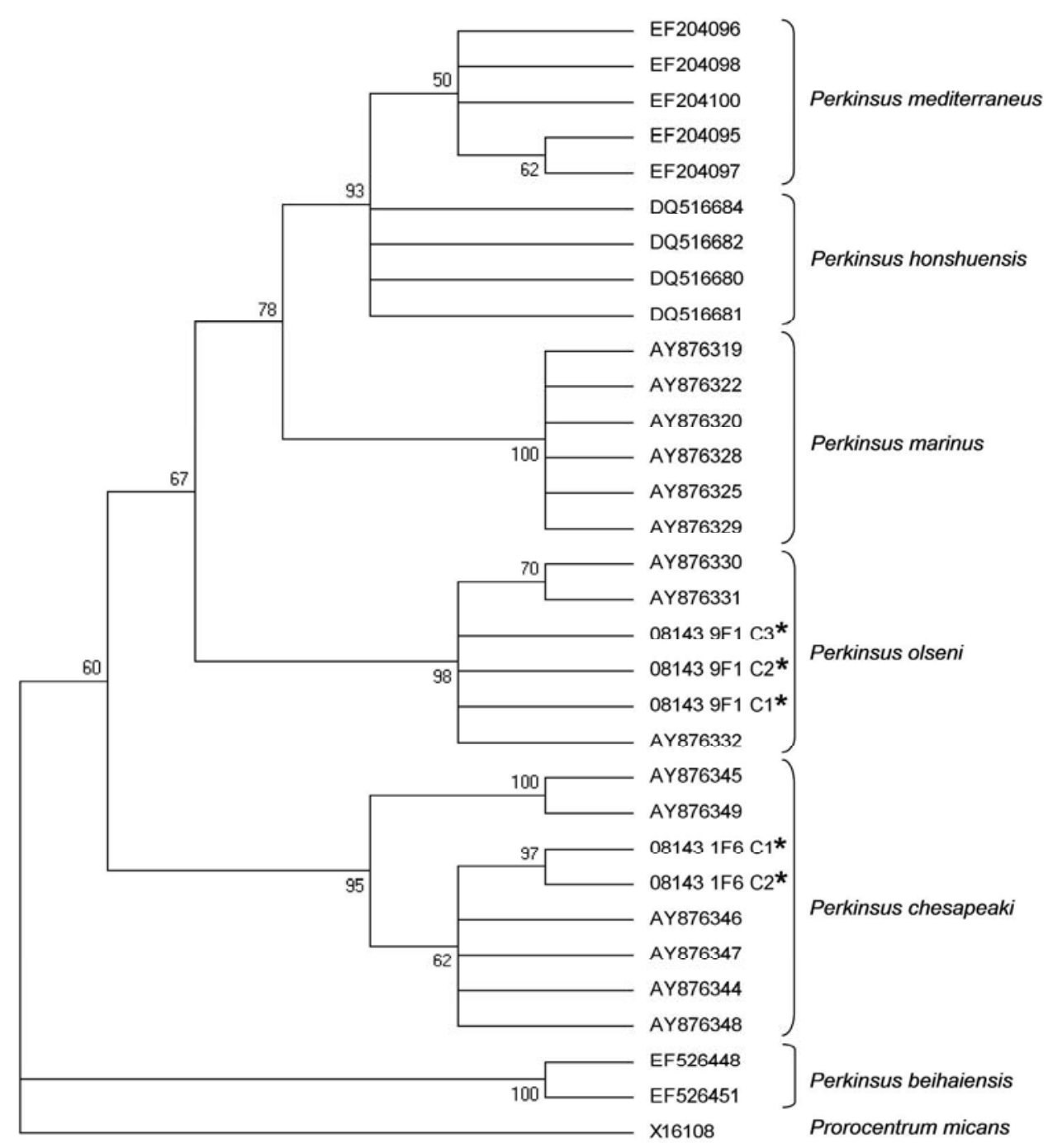

Figure 5. Maximum Parsimony analysis showing the taxonomic position of Perkinsus large subunit (LSU) rRNA gene sequences obtained in the present study. Numbers at branch nodes indicate bootstrap confidence values in percent. The analysis included 32 nucleotide sequences and was conducted using 984 aligned nucleotide positions. $\left(^{*}\right)$ sequences obtained in this study. 
Page 49 of 54

Parasitology
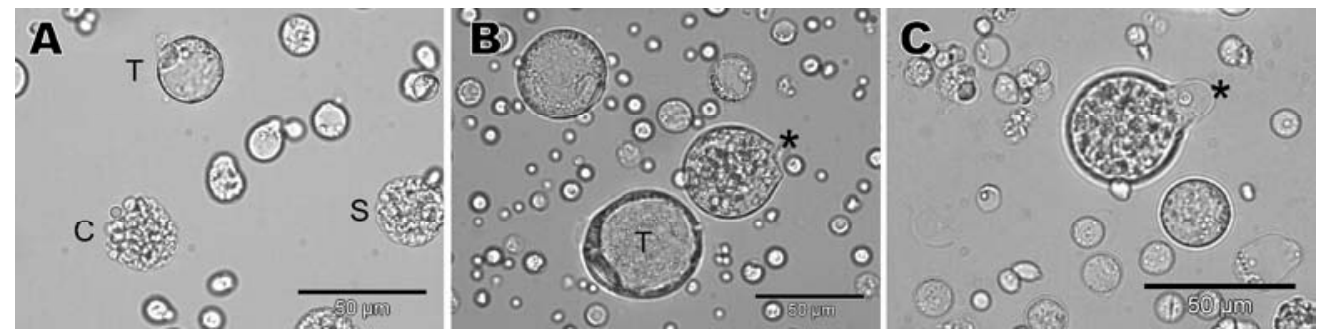

Figures $6 \mathrm{~A}, \mathrm{~B}$ and $\mathrm{C}$. In vito Perkinsus olsen (6A) and P. chesapeake (6B-C) cultures obtained from Ruditapes decussatus clams (Leucate Lagoon). 6A-Trophozoïte $(T)$ showing a typical signet-ring morphology with a large vacuole and eccentric nucleus, schizont (S) containing numerous daughter cells, cluster (C) of sibling daughter trophozoites. 6B- Trophozoite $(T)$ showing a typical signet-ring morphology with a large vacuole and eccentric nucleus, zoosporangium (arrow) with probable discharge tube $(*)$. bCZoosporangium (arrow) with extended discharge tube $(*)$ enclosing hundreds zoospores. Scale bars $=50$ $\mu \mathrm{m}$. 


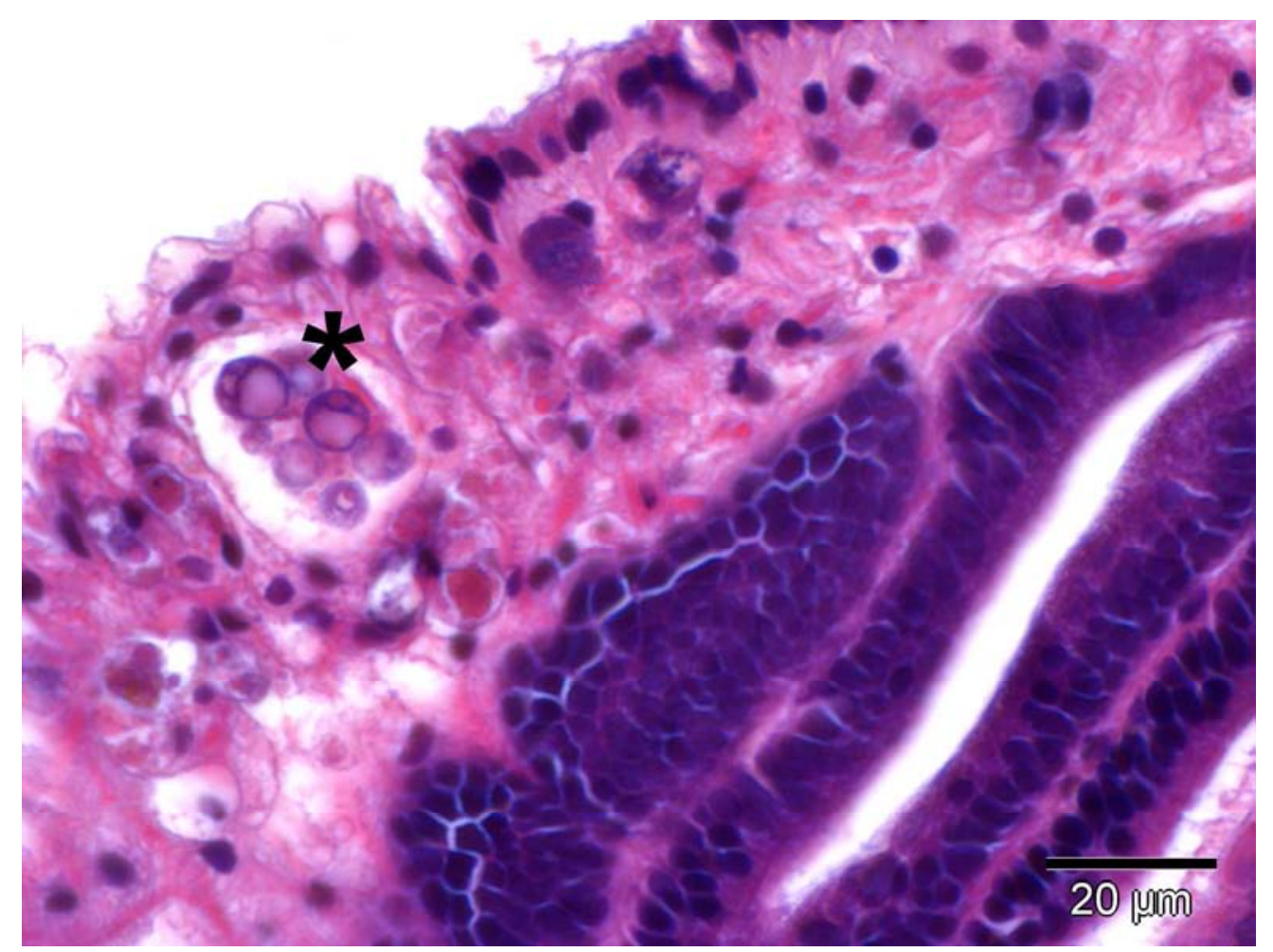

Figure 7-9. H\&E-stained tissue section showing Perkinsus trophozoïtes in tissues of Ruditapes decussatus from Leucate Lagoon. 7 Cluster of mature trophozoïtes inside an eosinophilic acellular matrix (*) showing an eccentric vacuole and a signet ring located in the connective tissue of the mantle. 


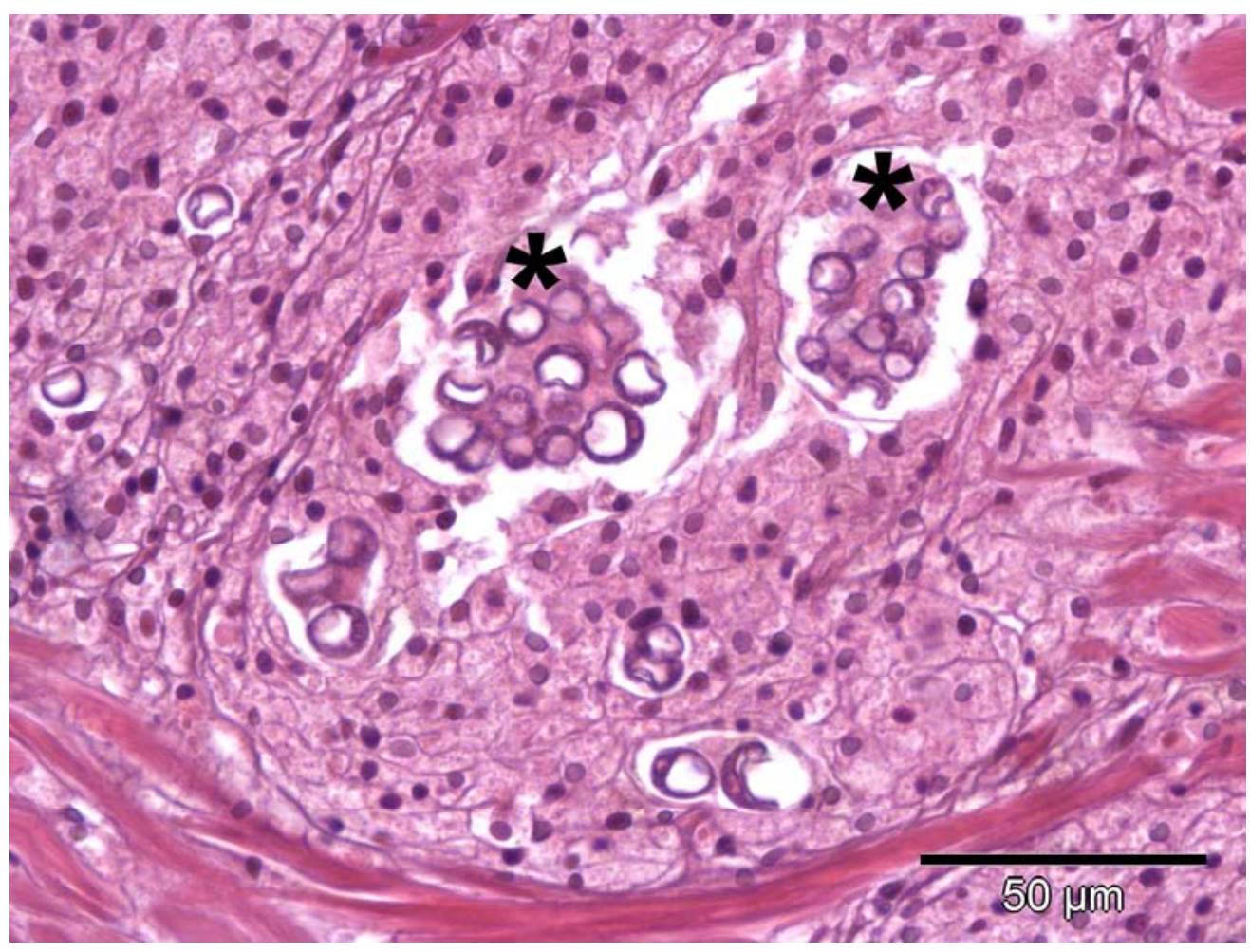

Figure 7-9. H\&E-stained tissue section showing Perkinsus trophozoïtes in tissues of Ruditapes decussatus from Leucate Lagoon.

8. Isolated or grouped trophozoïtes located in the connective tissue of the mantle. Parasite clusters are associated with eosinophilic acellular matrix $(*)$. 


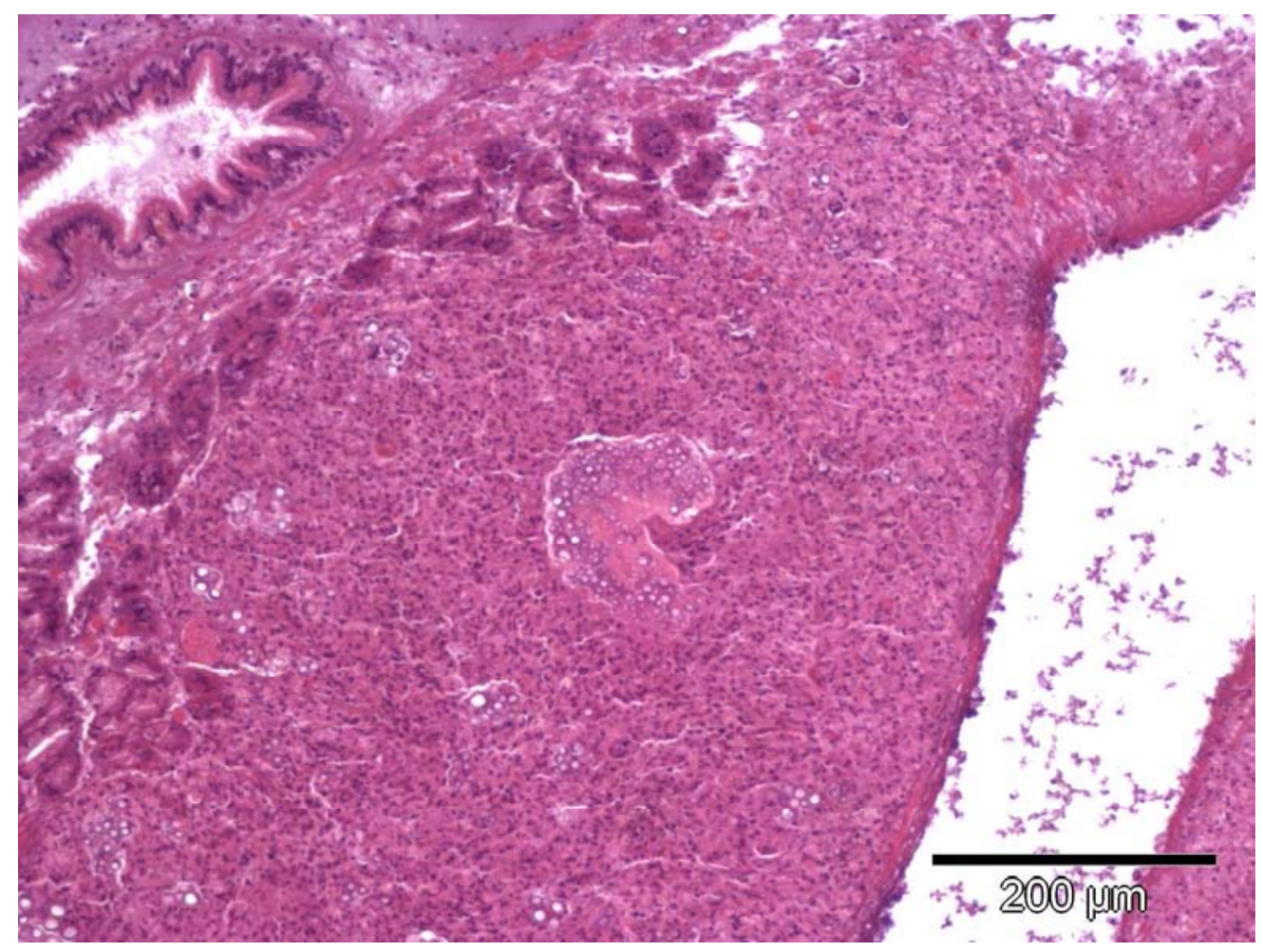

Figure 7-9. H\&E-stained tissue section showing Perkinsus trophozoïtes in tissues of Ruditapes decussatus from Leucate Lagoon.

9. Isolated and grouped trophozoïtes associated with an important infiltration of hameocytes in the connective tissue of the digestive gland. 

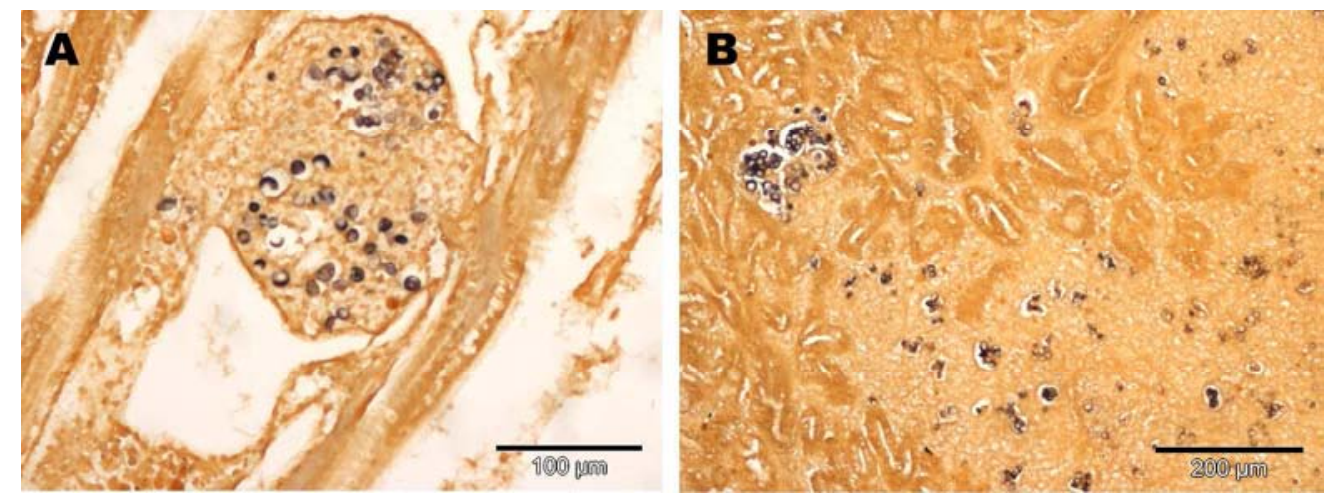

Figures $10 \mathrm{~A}$ and B. In situ hybridization assay using Perkinsus olseni probe on a clam Ruditapes decussatus from Leucate Lagoon. A. Positive isolated and grouped trophozoïtes in the connective tissue of gills. The presence of the parasites is associated with a strong haemocytic infiltration. B. Positive isolated and grouped trophozoïtes in the connective tissue of the digestive gland. 

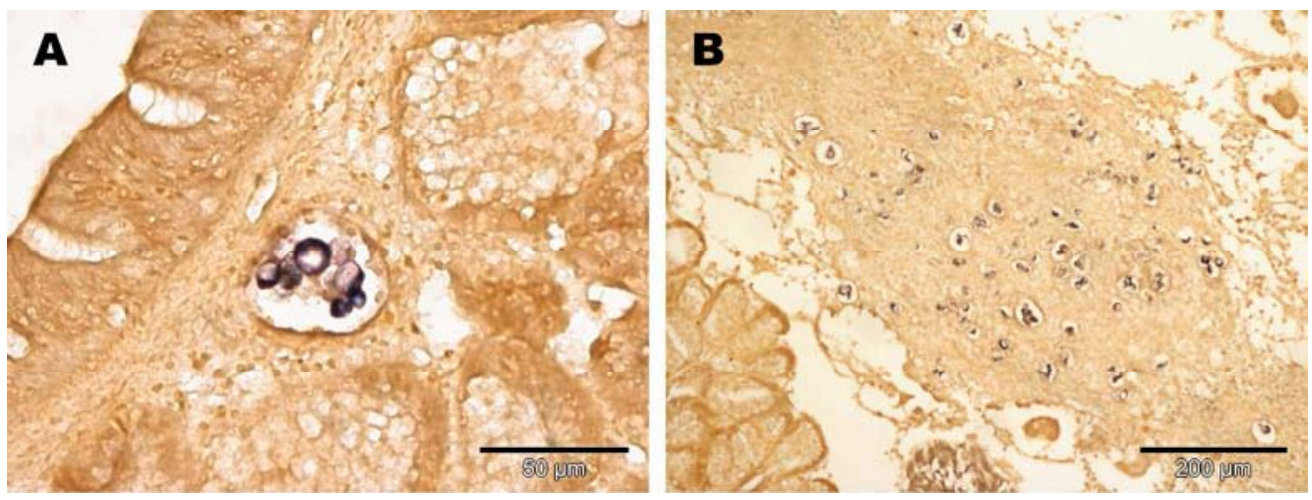

Figures $11 \mathrm{~A}$ and $\mathrm{B}$. In situ hybridization assay using Perkinsus chesapeaki probe on a clam Ruditapes decussatus from Leucate Lagoon. A. Encapsulated positive trophozoïtes in the connective tissue of the digestive gland. B. Positive isolated and grouped trophozoïtes in the gonadal connective tissue. 